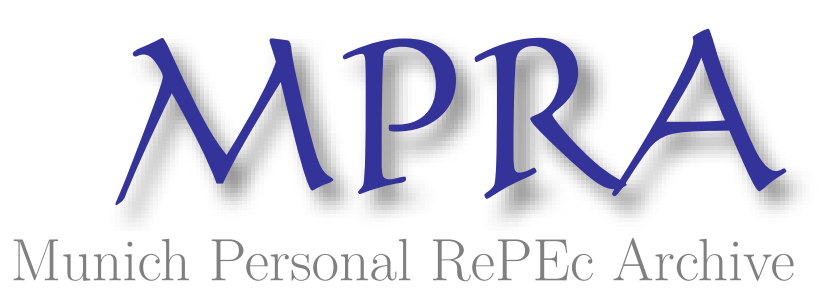

\title{
Korea investment corporation: its origin and evolution
}

Kim, Woochan

1 August 2011

Online at https://mpra.ub.uni-muenchen.de/44028/

MPRA Paper No. 44028, posted 28 Jan 2013 17:42 UTC 


\title{
Korea Investment Corporation: Its Origin and Evolution ${ }^{1}$
}

\author{
Woochan Kim \\ Professor \\ KDI School of Public Policy and Management \\ wc_kim@kdischool.ac.kr
}

August 2011

\begin{abstract}
In this paper, I give a detailed account of the creation and the evolution of Korea Investment Corporation (KIC) - a sovereign wealth fund established in 2005 by the Korean government. In doing so, I highlight three of its unique features. First, the case of KIC effectively shows the problem of having an unclear mission statement, which allows the mission to evolve over time and multiple missions to coexist that may contradict each other. Second, it effectively reveals the typical conflicts that may arise between the central bank and the ministry involved when setting up a reserve-based sovereign wealth fund. Third, it effectively shows how a sovereign wealth fund can be operated in a way that favors the bureaucrats and the politicians.
\end{abstract}

JEL Codes: F31, F34, G15, G23, G28, P16

Key words: Sovereign Wealth Fund, FX Reserve, Currency Crisis, FX Swap, Korea

${ }^{1}$ I thank Ludwig Linbo He, Yiping Huang, Takatoshi Ito, Andrew Rose and other participants at the East Asian Seminar on Economics (EASE) for their useful comments. 


\section{INTRODUCTION}

For the past few years, policy makers, market practitioners, and academics have shown keen interest in sovereign wealth funds (SWFs). Reflecting this interest, there is now an explosion of research papers on the topic. Amidst this growing interest, one strand of research that is also emerging is in-depth studies on individual funds. Yi-chong and Bahgat (2010) studies the political economy of sovereign wealth funds in China, Singapore, Kuwait, United Arab Emirates, Russia, Australia, and Norway. Clark and Monk (2010a, 2010b, 2010c, and 2011) also have a series of papers that study sovereign wealth funds in China, Singapore, and Norway. The purpose of this paper is to add another sovereign wealth fund to the list by giving a detailed account of the creation and evolution of Korea Investment Corporation (KIC) - a sovereign wealth fund established in 2005 by the Korean government.

KIC is a small sovereign wealth fund. As of December 2010, KIC manages 37.5 billion US dollars. According to the Sovereign Wealth Fund Institute, KIC ranks number 19 worldwide in terms of its total assets under management. ${ }^{2}$ Even among SWFs with non-commodity origin, it ranks number $8 .^{3}$ But, KIC has a number of unique features that make it quite interesting and also worth documenting. ${ }^{4}$

First, the case of KIC effectively shows the problem of having an unclear mission statement. It allows the mission to evolve over time and also allows inconsistent tenets within the mission statement to coexist and sometimes contradict each other. Before its creation, KIC has been discussed among policymakers as a macroeconomic policy tool, addressing issues such as surges of capital inflows. When Korea accumulated large FX reserves and experienced losses from reversed margin - higher domestic interest rate - and depreciation of US dollars, KIC has been discussed as a way to reduce the opportunity costs of holding large reserves. At the time of its creation, KIC was justified as an apparatus to promote Korea's onshore asset management industry and thereby transform Seoul into Northeast Asia's financial hub. Lastly, there is an emerging view that KIC should be used as a vehicle to prevent FX liquidity crises, such as the one Korea experienced in 2008/09.

Second, KIC is an example that effectively shows the typical conflicts that may arise between the

\footnotetext{
2 Abu Dhabi Investment Authority is the largest, managing 627 billion US dollars. This is followed by Norway's Government Pension Fund that manages 556.8 billion US dollars. For detailed rankings, visit Www.swfinstitute.org.

3 The top three are all Chinese: SAFE Investment Company (347.1 billion US), China Investment Corporation (332.4 billion USD), and Hong Kong Monetary Authority (HKMA) Investment Portfolio (292.3 billion USD). This is followed by Government of Singapore Investment Corporation (GIC), which manages 247 billion USD.

4 In March 2011, KIC's total assets under management are 43.5 billion USD. By the end of 2011, it is expected to increase by 51.5 billion USD. This will make KIC the $16^{\text {th }}$ largest SWF. 
central bank and the ministry involved when setting up a reserve-based sovereign wealth fund. ${ }^{5}$ Since KIC was to be set up by the Ministry of Finance and Economy (MOFE) and manage FX reserves owned and entrusted by the Bank of Korea (BOK) - the central bank - there were conflicts between the two, which had to be resolved initially by the Presidential Office and later at the National Assembly. ${ }^{6}$ BOK initially opposed the idea of setting up KIC on grounds that the level of reserve was not enough and that MOFE is trying to establish KIC to secure new positions for its required bureaucrats. Even when BOK agreed to entrust its foreign reserve assets, the dispute continued between the two. MOFE wanted to make BOK's entrustment mandatory and also prohibit BOK from imposing any investment restrictions. On the other hand, BOK wanted to enter an investment managing contract that gives to itself as much discretion as possible.

Third, the case of KIC effectively shows how a sovereign wealth fund can be operated in a way that favors the bureaucrats and the politicians. Despite the efforts made by a civil activist group and the opposition party, Korea adopted the Korea Investment Corporation Act under terms considerably favorable to the Ministry of Finance and Economy. ${ }^{7}$ The actual operation of KIC in subsequent years confirms such a claim. Its CEOs and auditors were often appointed among ex-bureaucrats. The level of disclosure is also kept at its minimum. People in senior positions were forced out during the first year of new Presidency.

The experiences documented in this paper can also be informative for the policy makers in other countries that are contemplating either to create a new sovereign wealth fund (e.g. Thailand) or to make their central banks entrust reserve assets to existing sovereign wealth funds that are currently managing its own capital (e.g. China).

This paper is organized as follows. Section II gives a detailed account of KIC's origin. In particular, I explore the various motives behind the creation of KIC in a chronological order. This is followed by the discussion on key issues that were debated during the legislative process among various stakeholders. A large portion of the discussion is allocated to the governance structure of KIC. Section III discusses the evolving views on KIC's mission and the actual operation of KIC after its creation. It also assesses KIC against the code of conduct set forth by the international community. Section IV concludes.

\footnotetext{
${ }^{5}$ Truman (2011) states that Asian SWFs that are disproportionately funded out of foreign exchange reserves will receive closer scrutiny than the SWFs of other countries.

${ }^{6}$ Such conflict did not arise in the case of China Investment Corporation (CIC). This is because CIC manages its own capital instead of managing reserve assets entrusted by the People's Bank of China. KIC, on the other hand, is an asset managing company managing assets owned and entrusted by BOK. This is the arrangement one can find between the Government of Singapore Investment Corporation (GIC) and the Monetary Authority of Singapore (MAS).

${ }^{7}$ In 2008, the Ministry of Finance and Economy (MOFE) was renamed as the Ministry of Strategy and Finance (MOSF).
} 


\section{THE ORIGIN}

\section{Background and Early Discussions (1999-2001)}

\section{Resurgence of Capital Inflows (1999 - )}

The very first time policy makers discussed the establishment of a Korean sovereign wealth fund - Korea Investment Corporation (KIC) - dates back to November 1999. By then, Korea had completely dispersed the concern over its foreign exchange liquidity condition. The KRW-USD exchange rate that peaked at

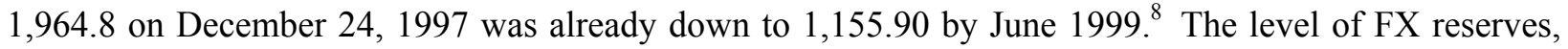
which was only 4 billion US dollars on December 18 1997, reached 70 billion UD dollars by November 1999.

Policymakers at the Ministry of Finance and Economy (MOFE) were instead troubled with an entirely opposite problem: surges of capital inflows. On top of a huge current account surplus (42.6 billion US dollars in 1998 and expecting well above 20 billion US dollars in 1999), they were expecting a surplus even in the financial account. In October, financial account switched to a surplus of 0.9 billion US dollars from a deficit of 1.6 billion US dollars in the previous month. In November, it recorded a 2.6 billion US dollars surplus. Foreign portfolio investment contributed $90 \%$ of this surplus. This made policymaker uneasy as surges of capital inflows may appreciate the domestic currency value, and then deteriorate the current account balance. A continued financial account surplus coupled with a chronic current account deficit was believed to be one of the key factors behind the 1997 crisis. The policy makers did not want to make Korea vulnerable again to sudden stop of capital inflows.

Engaging in sterilized FX market intervention was one solution, as it can insulate the exchange rate from capital inflows. But, it was also a controversial solution. Trading partners - the U.S. in particular may label such a practice an unacceptable exchange rate manipulation. An alternative measure was to encourage Korean residents to engage in overseas portfolio investment. Their demand for US dollars might mitigate the downward pressure on the KRW-USD exchange rate. By November 1999, MOFE was contemplating a measure to exempt overseas portfolio investment from the capital gains tax.

\section{Visit to Singapore and Hong Kong (November 29 - December 1, 1999)}

Against this backdrop, Ministry officials from the Foreign Exchange Policy Division made a business trip to Singapore and Hong Kong in late November. The purpose was to learn how the Government of

${ }^{8}$ During market hours, on December 24, 1997, the exchange rate went above the 2,000 level.

$$
-4 \text { - }
$$


Singapore Investment Corporation (GIC) works and how the central banks of Singapore and Hong Kong manage their FX reserves. ${ }^{9}$ The trip was short but fruitful. The Ministry officials realized that setting up a sovereign wealth fund similar to GIC might solve the dilemma they were facing. ${ }^{10}$ They learned that Singapore, a country that has adopted an exchange rate-based monetary policy, heavily intervenes in the FX market and transfers a significant portion of its FX reserves to GIC. ${ }^{11}$ It is no coincidence that the year Singapore adopted the exchange rate-based monetary policy (1981) is also the year GIC was established. By December, the merits of establishing a sovereign wealth fund were well understood within the Ministry.

An internally circulated document summarized the merits and lessons learned in four areas. ${ }^{12}$ First, such a fund would allow Korea to maintain a current account surplus even in the midst of continued capital inflows. If a significant portion of FX reserves is transferred to a newly established sovereign wealth fund, the reserve would accumulate much more slowly, and thus engender less controversy over Korea's FX market intervention. This obviously would give the government more room to intervene. Second, it would allow Korea to benefit from economies of scale. Following Singapore's example, Ministry officials were thinking of a sovereign wealth fund that manages not only FX reserves, but also the overseas assets held by the National Pension Fund and state-owned enterprises. ${ }^{13}$ Third, it would enable the Korean government to get better access to high quality market information. Ministry officials believed that having such access is crucial in preventing currency crises. Fourth, it can serve as a catalyst in developing Korea's asset management industry. Ministry officials were intrigued how Singapore was using GIC and the Monetary Authority of Singapore (MAS) as vehicles to spur development in the Singapore fund management industry. The document reports that GIC and MAS earmarked 35 billion SGD (approximately 19 billion US dollars; 25 billion SGD from GIC and 10 billion SGD from MAS) to be placed out to external managers, regardless of nationality, during 1998-2000. The Ministry officials also believed that the know-how on overseas investment accumulated within the sovereign wealth fund might later trickle down to other Korean funds, and thereby contribute to the development of Korea's

\footnotetext{
${ }^{9}$ The author of this paper headed this mission trip. The trip, however, was first suggested by Hongchul (Hank) Ahn, who was working at the Korea Center for International Finance (KCIF) at that time. KCIF is an organization established by the Korean government and the Bank of Korea in 1999 to monitor movements in international financial markets and issue early warning signals. Mr., Ahn later served as the Auditor of KIC.

${ }_{10}$ At that time, the term "sovereign wealth fund" was not yet used.

${ }_{11}^{11}$ On Singapore's unique monetary policy, see Parrado (2004).

12 The author of this paper authored this internal document.

${ }^{13}$ It was expected that the size of National Pension Fund (NPF) would be phenomenal. The most recent projection, made in 2008, states that the fund will peak in 2043 at 2,607 trillion KRW (approximately, 2.5 trillion US dollars). NPF was established was established by the National Pension Act to serve as a reserve fund to meet the liabilities of the National Pension Scheme.
} 
asset management industry.

\section{Deterioration of BOK's Balance Sheet (2000-2001)}

In 2000 and 2001, the Ministry of Finance and Economy informally floated the idea of establishing Korea Investment Corporation (KIC). In August 2001, Minister Jin Nyum stressed the importance of improving returns on BOK's FX reserves. He expressed concerns that the returns on FX reserves were well below the interest BOK paid on its monetary stabilization bonds (denominated in KRW). ${ }^{14}$ The Minister clearly had in mind setting up KIC. By then, the size of Korea's FX reserve reached 98 billion US dollars.

BOK's response, however, was negative. An anonymous interviewee from BOK showed concern that the size of the FX reserve was not yet large enough, and therefore, securing liquidity should have priority over improving investment returns. BOK also criticized what it perceived to be MOFE's intention to establish KIC in order to secure new positions outside the Ministry for its retired bureaucrats.

\section{President Noh and Northeast Asia Financial Hub (December 2002 - March 2004)}

\section{President Roh's Election Pledge (December 2002)}

The discussion of establishing KIC submerged for more than a year. A window of opportunity, however, opened with the new administration that set the goal of making Seoul a preeminent financial center in Northeast Asia. During the election campaign in late 2002, presidential candidate Roh Moo-hyun pledged that he would transform Korea into Northeast Asia's business hub in terms of distribution, finance, and trade. $^{15}$ But it was not until January 2003 when the President-elect and the Transition Committee seriously considered the possibility of pursuing that transformation. In April 2003, soon after President Roh's inauguration, Korean government established a new task forced named the Presidential Committee on Northeast Asia Business Hub. ${ }^{16}$ It was decided that the road map for this project would be jointly prepared by the Presidential Committee and MOFE.

\section{MOFE versus BOK (November 2003 - December 2003)}

The road map was officially released on December 11, 2003. But, even before then, popular press started

14 See Kukminilbo (August 27, 2001). The interview took place around the time Korea fully repaid its IMF stand-by loans (19.5 billion USD), three years ahead of schedule.

15 This idea was not new. It was originally proposed by former President Kim Dae-jung in May 2000 at the Asia-Europe Meeting (ASEM) summit.

16 Originally, the committee was named the Presidential Committee on the Northeast Asia Business Center. China and Japan - two other Northeast Asian countries - informally showed concerns over using the term "center."

$$
-6-
$$


to report that government would establish KIC. ${ }^{17}$ They reported that approximately 10 percent of FX reserves would be transferred to $\mathrm{KIC}$, and that professionals from the private sector would comprise its entire staff. This triggered strong resistance from BOK. Its opposition rested upon the following six points. ${ }^{18}$

First, BOK refuted the idea that the level of Korea's FX reserve was excessive. BOK argued that the appropriate level of FX reserve should be around 300 billion US dollars if one considers the North Korean factor. The FX reserve had only reached 150 billion US dollars as of November 2003. Second, BOK repeated its earlier argument that securing safety and liquidity should have priority over improving investment returns when managing FX reserves. Third, BOK disproved the claim that it was experiencing a loss due to reversed margin. It disclosed its FX reserve asset returns during 1998-2002, which is an unusual practice for a central bank. According to BOK, the return was on average $6.14 \%$ per annum during the period. It also stressed that its return on investment surpassed the yield on a 2-year monetary stabilization bond (MSB) during 2000-2002. Fourth, BOK repeated its earlier criticism that MOFE is trying to establish KIC to secure new positions outside the Ministry for its retired bureaucrats. Fifth, BOK criticized the plan of transferring it reserve assets to KIC separate from its debt. BOK argued that KIC should also assume BOK's debt. This concern, however, was soon dropped. Government officials clarified the following day that there would be no change in the ownership of reserve assets. KIC would be one of BOK's external managers ${ }^{19}$.

On December 5, BOK delivered to the Presidential Committee its official statement opposing the establishment of KIC. Also, it was around this time that China's plan to establish China Investment Corporation (CIC) became known. ${ }^{20}$ This worked in favor of the Presidential Committee and MOFE.

\section{The Road Map for Northeast Asia Financial Hub (December 2003)}

On December 11, 2003, the Presidential Committee and MOFE jointly laid out their road map to transform Seoul into Northeast Asia's "niche" financial hub, with a target of 2012 for completion. The Committee intentionally used the term "niche" to indicate that Seoul did not aspire to become a global

17 The earliest news reports were released on November 27, 2003.

${ }^{18}$ For details, see BOK's press release dated December 4, 2003.

19 This is in contrast to China Investment Corporation (CIC), which manages its own capital instead of managing reserve assets entrusted by the People's Bank of China. By issuing special purpose debt, the Ministry of Finance raised Chinese Yaun, which was in return used to purchase foreign reserve assets from the People's Bank of China. These reserve assets were invested as CIC's equity capital. CIC was established in 2007.

20 Japan also considered setting up its own reserve-based sovereign wealth fund. But, it has not yet materialized. Unlike Korea and China, Japan's FX reserve is owned and managed by the Ministry of Finance.

$$
-7-
$$


financial center in the ranks of NYC or London. Its aim, instead, was to become a regional hub similar to Hong Kong or Singapore. Thus, Seoul set its sights on a particular subset of the financial industry. That is, the asset management industry. ${ }^{21}$

The Committee laid out a number of rationales behind this decision. First, asset management is an industry that requires minimal investment in tangible assets, which makes it highly mobile, and therefore easier to relocate. Second, its growth would enlarge and deepen Korea's capital market, then considered small relative to the size of its economy. Third, the demand for asset management service was then growing rapidly. The life expectancy was increasing and the size of assets managed by National Pension Fund was expected to reach $50 \%$ of GDP by 2040 . Fourth, despite its growth potential, Asia's asset management industry still lagged behind those of other regions.

But the proposal that attracted the most attention was establishing KIC. As its raison d'être, the road map laid out three points. Obviously, one was managing part of FX reserves in more lucrative assets. The second was to attract foreign asset management companies to Seoul, and thereby transform Seoul into Northeast Asia's "niche" financial hub. As a way of doing this, it suggested that KIC give mandates to foreign asset management companies, and thereby induce them to relocate to Seoul. As mentioned earlier, this is precisely the measure Singapore took in 1998. The joint report also mentioned that setting up KIC would allow Korea to get better access to high quality market information from its service provides. Interestingly, the joint report did not mention the need to use KIC as a countermeasure against capital inflows. The Presidential Committee and MOFE must have considered it inappropriate to explicitly disclose such a purpose, even if it was true.

The joint report also set forth the basic legal and financial structure of KIC. First, it was decided that a separate bill establishing KIC be prepared for submission to the National Assembly. ${ }^{22}$ Second, it specified that KIC be established as a corporation and its initial equity capital would be 200 billion KRW (approximately, 200 million US dollars). Third, its equity would be fully owned by the government. Fourth, at its initial stage, KIC was to manage 20 billion US dollars, or 13\% of the total FX reserves. Note that Korea's total FX reserve assets are not only held by BOK, but also by the Foreign Exchange Stabilization Fund. The latter fund is managed by MOFE and takes up approximately 15 percent of total reserves. The joint report stated that, in the long-run, KIC will manage not only the FX reserve assets, but also the overseas assets held by the National Pension Fund and other state-owned enterprises. The report projected that this would ultimately make the total assets under management (AUM) greater than that of GIC. Fifth, it was decided that, in the beginning, KIC should invest only in overseas assets. It was also

${ }^{21}$ The road map also set 2020 as the target year to transform Seoul into Asia's top 3 financial centers.

${ }^{22}$ National Assembly is the name of Korea's legislative branch. 
decided that, in its initial stage, KIC manage the assets through external managers.

The joint report also gave some basic directions on the governance structure of KIC. First, establish the Management Evaluation Committee that would oversee the management of KIC. The Committee should be composed of shareholder representatives - government representatives as ex officio members and other financial experts outside the government. ${ }^{23}$ Second, the Committee must hire a CIO, separate from a CEO. The CIO should be appointed regardless of nationality and also be subject to strict eligibility requirements to ensure his/her investment management expertise. Also, set the level of compensation high enough to attract talented managers for the position. Third, adopt a system where pay is tightly linked to long-term performance. Fourth, adopt measures that can minimize the risk of National Assembly and Board of Audit and Inspection (BAI) interfering into day-to-day management. ${ }^{24}$ Also, in case of sensitive information on KIC's investment management, provide them to the National Assembly and to BAI only on a confidential basis.

\section{Consulting Project Commissioned by the Committee (January10 - March 24, 2004)}

The detailed governance structure, however, was not agreed upon between MOFE and the Presidential Committee. The two instead decided that the Presidential Committee commission a consulting project on the governance structure of KIC to outside experts. The idea was to incorporate the suggestions made by the consulting report when MOFE drafted the Korea Investment Corporation Act. This project was carried out by a team of governance experts from January to March $2004 .{ }^{25}$ The consultants made a visit to GIC, MAS, and HKMA (January 11-14), studied other sovereign wealth funds, and came up with detailed recommendations. The key features of the final report, dated March 25 2004, are summarized as follows. ${ }^{26}$

First, the report proposes four guiding principles that should be used to shape the governance structure of KIC. They include (i) accountability to the shareholders (government) and ultimately to the

\footnotetext{
${ }^{23}$ Since the Committee will not have any executives as its members, the establishment of Management Evaluation Committee presumes a two-tier board system.

${ }^{24}$ The Board of Audit and Inspection (BAI) is a constitutional agency established to audit the accounts of the State and to inspect the works performed by government agencies.

${ }^{25}$ The author of this paper led the consulting team. There were two other members in the team: Park, Kyung-Suh (Professor, Korea University Business School) and Lim, Wonhyuk (Fellow, Korea Development Institute)

${ }^{26}$ The report also provided a number of reasons why KIC should be established separate from BOK. First, as a public organization, $\mathrm{BOK}$ does not have the commercial incentives to improve the returns on its assets. Second, BOK does not have the compensation system that can attracted talented investment managers. Third, even if BOK does adopt such a system, this will only foster disharmony between investment managers and others. Fourth, as an organization managing FX reserves, BOK is not appropriate to be subject to external monitoring. 
public in general, (ii) independence from other government policies, (iii) managerial autonomy and leadership, and (iv) investment expertise and commercial incentives for managers. The four principles, however, may contradict each other. For example, too much emphasis on accountability may make KIC less independent from government. To resolve such conflicts, the report suggests setting clear ex ante rules and procedures. Once such rules and procedures are set and disclosed, it would be very hard for the government to intervene in the management of KIC and carry out arbitrary performance evaluations. In this case, accountability would be judged solely based on the managers' compliance with such rules and procedures. Autonomy can also be ensured by giving a reasonable degree of discretion to the managers within the pre-set rule and procedures. $<$ Figure $1>$ shows the relationship among the four principles.

Second, on internal control, the report proposes to adopt a single-tier board system. That is, one board would perform two functions, supervisory and managerial. Under this system, the board would be composed not only of shareholder representatives (government) and outside independent directors, but also some executives. ${ }^{27}$ This is in contrast to the earlier proposal to set up Management Evaluation Committee, which does not have any executive members, and therefore presumes a two-tier board system. The report saw more drawbacks from a two-tier system than from a single-tier system. First, given that the National Assembly and BAI may exercise some supervisory roles, having a separate supervisory board is redundant. Second, if the supervisory board becomes inactive or obsolete because of its redundancy, there will be no role for the outside directors to play. Third, if responsibilities are not clearly defined ex ante between the two boards, they may shift the blame to each other ex post. On candidate nomination, the report proposes to establish a nomination committee, the members of which are, in turn, appointed by the National Assembly, MOFE, and BOK. ${ }^{28}$ On eligibility requirements, the report proposes that former government officials or BOK employees cannot serve as board members unless five years have passed since their departure. Also, the report proposes that executive board members have working experience in the field of investment management for at least 10 years.

Third, on external discipline and monitoring, the report stresses the importance of transparency in KIC's investment management practices. ${ }^{29}$ Although, board meeting minutes and voting results need not

27 The report proposes a board composed of nine members (independent chair, other five outside directors, $\mathrm{CEO}$, and two ex officio members from MOFE and BOK).

${ }^{28}$ When nominating outside director candidates, the report proposes a nomination committee composed of 6 members ( 2 appointed by the Speaker of the National Assembly, 2 appointed by the Minister of Finance and Economy, and 2 appointed by the Governor of BOK). When nominating a CEO candidate, the report proposes a nomination committee composed of 12 members (add 6 outside directors to the outside director candidate nomination committee).

${ }^{29}$ In this regard, the experts that drafted the report had in their minds the Norwegian Petroleum Fund as KIC's benchmark. Norway's Government Pension Fund - its new name since 2006 - is known for the level of its transparency. MOFE, on the other hand, was using GIC as KIC's benchmark. GIC is far from being 
be disclosed, it emphasizes that KIC's investment policy statement (IPS), its sub-rules, and related procedures be fully disclosed. It also stresses public disclosure of detailed investment management results. Exceptions would be yearly asset allocation plans and individual securities held by KIC, the disclosure of which may produce more problems than benefits. Such prescriptions are in contrast to the earlier proposal prepared by MOFE and the Presidential Committee that supports minimal public disclosure. The report also emphasizes that private sector institutions - accounting firms and global custodians - play external disciplinary and monitoring roles in addition to the National Assembly and BAI.

Fourth, on KIC's investment policy statement, the report stresses that it is strongly preferable that KIC have a single mission and explicitly argues that "maximizing international purchasing power, taking into account an acceptable level of risk" should be the sole mission of KIC. ${ }^{30}$ To give constituents a clear sense of direction, the report emphasizes that KIC's IPS makes it clear that other objectives, such as promoting onshore asset management industry, are subordinate to the mission stated above. On KIC's portfolio, the report proposes to ban investments in KRW-denominated assets by law. It expresses concerns that, if domestic investments are allowed, government officials or politicians may be tempted to misuse KIC in their favor. The report also stresses that KIC adopt a clear proxy voting guideline. Finally, it makes it clear that the decision to let KIC manage the overseas assets of National Pension Fund (NPF) lies solely in the hands of NPF Management Committee members.

\section{Key Issues and Legislative Process (April 2004 - March 2005)}

\section{Presidential Committee versus MOFE (April 2004 - June 2004)}

Even before the Presidential Committee finalized its proposal on the governance structure of KIC, MOFE came up with its first draft of the Korean Investment Corporation Act. Since then (April 17), MOFE has gone through at least seven revisions before the government finally submitted the bill to the National Assembly on September 20, 2004. ${ }^{31}$ Over this five-month period the Presidential Committee and MOFE heatedly debated the bill's provisions. ${ }^{32}$ In this subsection, I outline the key issues.

\footnotetext{
managed in a transparent way.

30 This is also the mission statement of Norwegian Government Petroleum Fund. This fund was renamed in 2006 as the Government Pension Fund of Norway.

31 Revision dates are April 17, April 30, May 3, May 19, June 18, June 24, and September 20.

32 From the Ministry of Finance and Economy, the key officials involved in the negotiations include: Choi, Joong-Kyung (Director-General, International Finance Bureau), Choi, Jong-Ku (Director, International Finance Division, International Finance Bureau) and Min, Kyung-Seol (Deputy Director, International Finance Division International Finance Bureau). From the Presidential Committee on Northeast Asia Business Hub, the key officials involved in the negotiations include: Chung, Tae-In (Executive Director), Choi, Myung-Ju (Chair, Financial Hub Sub-committee), Lee, Keon-Beom (Secretary, Finance Team) 
- First, KIC's mission statement itself generated considerable debate. In MOFE's initial draft, KIC had to serve two objectives, one to enhance the efficiency in managing FX reserves and other public funds, and the other to contribute to the nation's economy. Negotiations with the Presidential Committee, however, led MOFE to regard the first as an intermediate goal and the second as the ultimate goal. The final September bill states that KIC is established to enhance the efficiency in managing assets entrusted by the Government, the BOK, and others, and thereby pursue the development of the financial industry and contribute to the nation's economy. Thus the mission statement remains vague and elusive.

- Second, the Presidential Committee and MOFE hotly debated the question of board structure. The Presidential Committee supported the single-tier board system, following recommendations made in the consulting report, while MOFE supported the two-tier system. MOFE argued that a single-tier system cannot be justified in the absence of an entity that serves the function of a shareholders' meeting. MOFE also argued that most of the state-owned corporations in Korea have a two-tier system. In the end, the two sides struck a compromise, that KIC will have a two-tier system, but KIC's President will be a member of both boards. ${ }^{33}$ In the government's final bill, the board with the supervisory role was named the Steering Committee, while the management board was named Board of Directors.

- Third, there were disagreements on how Civil Members will be appointed. MOFE's initial draft prescribed that there be three Civil Members: one appointed by the Chairman of the Korea Federation of Banks (KFB) among commercial bank presidents, another appointed by the Chairman of the Korea Securities Dealers Association (KSDA) among securities firm presidents, and lastly one appointed by the President of the Korean Institute of Certified Public Accountants (KICPA) among accounting firm presidents. Given the influence MOFE can exert over these trade associations, it was doubtful that they can be independent from MOFE and perform the necessary monitoring role. The Presidential Committee, on the other hand, supported the position taken in the consulting report, that is, establishing an Outside Director Nomination Committee, the members of which are, in turn, appointed by the National Assembly, MOFE, and BOK. In the end, a compromise was made. In the government's final bill, Civil Members are nominated by a committee composed of at least six members: two appointed by the Minister of Finance and Economy, two by the Minister of Planning and Budget, two by the Governor of BOK, and two by the head of every other organization entrusting

33 The decision to go for a two-tier system was influenced by President Roh. He favored the two-tier system. 
assets to KIC above a certain threshold. MOFE had a strong opposition to the idea of giving politicians the power to appoint Nomination Committee members. According to the final bill, the Steering Committee is composed of six Civil Members, the KIC President, and the heads of organizations entrusting more than the amount prescribed in the Presidential Enforcement Decree.

- Fourth, MOFE's initial draft was very lax on the expertise requirement for Civil Members. They only had to have experience and knowledge in the areas of the financial industry and corporate management. Working experience in the investment management industry was not a necessary condition. Moreover, MOFE's bill was completely silent on the expertise requirement of KIC executives. In response to the Presidential Committee's criticism, MOFE revised its bill. The government's final bill states that Civil Members of the Steering Committee and KIC executives must have expertise in the asset management industry. Detailed requirements, however, were delegated to the Presidential Enforcement Decree.

- Fifth, in regards to board chairs, MOFE proposed a co-chair system. Under MOFE's proposal, the Minister of Finance and Economy and any other member representing an organization entrusting assets more than a certain threshold, would serve as co-chairs of the Steering Committee. The Presidential Committee, on the other hand, proposed that outside board members rotate to serve as chairman. On this issue, the Presidential Committee's proposal won over that of MOFE.

- Sixth, in regards to internal audit, MOFE wanted to have a statutory auditor, while the Presidential Committee wanted an audit committee. According to MOFE's draft, the auditor is exclusively appointed by the Minister of Finance and Economy. Under the Presidential Committee's proposal, a subset of independent outside board members serves as audit committee members. The Presidential Committee criticized that an auditor appointed by the Ministry of Finance and Economy can never be independent from the Minister, and therefore will not be able to carry out its auditing role. Despite such criticism, MOFE's initial position won over that of the Presidential Committee.

- Seventh, on the appointment of KIC's President, MOFE initially proposed that the Minister of Finance and Economy have the exclusive right to nominate the candidate to the President. The Presidential Committee, on the other hand, proposed that the candidate be nominated by the Presidential Nomination Committee, composed of outside directors and members in the Outside Director Nomination Committee. This is exactly the proposal taken in the consulting report. In the end, the Presidential Committee and MOFE compromised. The government's final bill requires the Minister of Finance and Economy to consult with the Steering Committee before nominating the candidate to the President.

- Eighth, on external audit, MOFE initially proposed that the Board of Audit and Inspection (BAI) have $-13-$ 
no power over KIC. According to this draft, National Assembly is the only outside entity that can request information from KIC. The Presidential Committee, on the other hand, proposed that BAI, in addition to the National Assembly, have power to audit and inspect KIC. On this matter, MOFE yielded to the Presidential Committee.

- Ninth, on transparency, MOFE's initial draft had no related provision. The Presidential Committee, however, proposed that KIC disclose its financial statements, investment policy, and investment performance. The Presidential Committee's proposal delegated the details of this disclosure to the Presidential Enforcement Decree. Negotiations between the two led MOFE to revise its draft. According to the bill submitted to the National Assembly, KIC must disclose the basic directions of its investment policy and the overview of its investment performance. MOFE was not enthusiastic about transparency. According to this bill, the details on this disclosure were delegated to KIC's articles of incorporation (AOI).

- Tenth, on the relationship with asset entrusting organizations, MOFE's initial draft states that the Minister of Finance and Economy can request any public institution, provided that they are listed in the Presidential Enforcement Decree to entrust the management of its assets to KIC, and upon such request, those institutions cannot refuse. Furthermore, the draft states that any investment management contract between asset-entrusting organizations and KIC cannot have provisions that can restrict the way KIC manages the entrusted assets. The Presidential Committee strongly opposed such draconian provisions, which led MOFE to revise the bill.

\section{Government versus PSPD (June 2004 - September 2004)}

The government's bill had to overcome a number of hurdles before it finally passed at the National Assembly in March 2005. Since the public notice of the bill on June 18, 2004, the government had to confront strong opposition from the People's Solidarity for Participatory Democracy (PSPD) - Korea's largest civil activist group - and the Grand National Party, the opposition party during President Noh's Presidency. Bank of Korea (BOK) also vehemently opposed it. BOK was particularly concerned with the provision allowing the investment management contract between KIC and the entrusting organizations to be dictated by the Presidential Enforcement Decree, which was drafted and de facto controlled by MOFE. The International Monetary Fund (IMF) also expressed its views on establishing KIC. In the 2003 Article IV Consultation Staff Report (released in February 2004), IMF staffs stressed the importance of safeguarding the independence of KIC and the transparency of its operations. ${ }^{34}$

${ }^{34}$ On page 26, the report states "....the staff recognizes that the aim is to spur the development of the asset -14 - 
On July 5, 2004, two weeks after MOFE's public notice of the bill, PSPD held a press conference to alert the public to the problems with the KIC bill. PSPD did not oppose the need to establish KIC. It concurred that excess FX reserves need to be invested in more lucrative assets. But, it was concerned with the governance structure and the level of transparency the bill prescribed. The following is the outline of the proposal laid out at the press conference. ${ }^{35}$

First, PSPD was concerned that the bill was giving the Minister of Finance and Economy too much power over KIC. According to the draft bill of June 18, the Ministers tasks were to approve the Articles of Incorporation (AOI) of KIC, nominate the KIC President candidate, appoint the Directors and Auditor of $\mathrm{KIC}$, and request asset-entrusting organizations to hire KIC as its external manager. PSPD argued that such concentration of power in the hands of the Minister would make the Steering Committee obsolete. To let the Steering Committee take a leadership role and to let Civil Members effectively monitor the Ministry, it was important that such functions be performed, not by the Minister, but by the Steering Committee.

Second, PSPD was concerned with the level of transparency the draft bill prescribed. It stressed that the secrecy of its management could not be justified on grounds that disclosure might weaken the government's ability to defend its currency in times of crisis. KIC would be managing excess reserves not likely to be used in FX market interventions. It also stressed the importance of disclosing KIC's target policy mix and the actual allocations. Once disclosed, politicians or bureaucrats would have a hard time influencing KIC to invest more in certain asset classes. PSPD also emphasized that a sufficient level of disclosure would allow the general public to directly monitor KIC and pressure the National Assembly and BAI to carry out their monitoring roles more effectively. In the absence of such public disclosure, PSPD worried that the two organizations would suffer from moral hazard problems.

Third, PSPD expressed concerns over delegating important decisions to the Presidential Enforcement Decree and to the Articles of Incorporation. Once delegated, the National Assembly would have no control over the matter, and there was a possibility that MOFE might water down the requirements. An example is the eligibility requirements for Civil Members who would serve on the Steering Committee. Given the importance of ensuring their independence and expertise, it was strongly

management sector, rather than to provide a mechanism to intervene in the market or a substitute for exchange rate flexibility. However, it believes that strong safeguards are necessary to guard against the risks involved. The agency's law should guarantee its operational independence, investment guidelines, and rules for any future transfer of reserves. Moreover, the KIC's accounts should be regularly and fully disclosed to the public, and it should refrain from investing domestically, at least until its credibility is established." The author of this paper had a meeting with the IMF Resident Representative (Kenneth Kang) in December 2003 and with the IMF mission team in May 2004.

${ }_{35}$ Among many action bodies of PSPD, this press conference was organized by the Economic Reform Center. As a member of this Center, the author of this paper drafted the proposal. 
advised that detailed provisions be stipulated in the Act. This was also the position taken in the consulting report commissioned by the Presidential Committee. On matters related to subcommittees, compliance, and investment ethics, the draft bill was completely silent, in effect delegating detailed provisions either to the Presidential Enforcement Decree or to the Articles of Incorporation.

Fourth, PSPD pointed out that Steering Committee would suffer from a structural problem as it pursued two conflicting interests. According to the draft bill, the Steering Committee was to be composed of members representing shareholders (the Minister of Finance and Economy), asset-entrusting organizations (the Governor of BOK, the Minister of Finance and Economy, and other public organizations in the future), and the general public (Civil Members). It was not hard to see that the interests of asset-entrusting organizations and that of asset managers would be in conflict. Each party would be involved in decisions that ought to be determined solely by the other party. Thus PSPD suggested removing members representing asset-entrusting organizations from the Steering Committee.

In addition to the proposals mentioned above, PSPD made many others. It suggested (i) prioritizing multiple missions, (ii) removing asset entrusting organizations and managers from the Civil Member Nomination Committee to ensure the Committee's independence, (iii) introducing a provision on whistleblowing, (vi) giving asset entrusting organizations the exclusive right to make decisions on withdrawal, investment restrictions, and management fees, (vii) writing up a short list giving KIC the power to veto public disclosure instead of giving KIC discretionary veto power, and (viii) making it mandatory for KIC to be subject to external audit by private-sector accounting firms, in addition to audit and inspection by BAI.

PSPD's public criticism helped the Presidential Committee persuade MOFE to make further revisions to the draft bill before its final submission to the National Assembly in September. It also heavily influenced the National Assembly that later revised the bill substantially.

\section{Government versus National Assembly (November 204 - March 2005)}

The bill was submitted to the National Assembly on September 17, 2004. But it was not until November 17 that the National Assembly started to discuss the bill. On November 26, the Finance and Economy Committee - the standing committee at the National Assembly overseeing the Ministry of Finance and Economy - organized a public hearing. Among the four experts summoned, two opposed the bill, while the other two supported it. Concerns raised by the opposing witnesses can be summarized as follows. ${ }^{36}$

${ }^{36}$ The author of this paper was one of the four that testified before the committee. The summary is based on my own testimony. 
First, they raised concerns that the missions granted to KIC - promoting the advancement of the financial industry and contributing to the nation's economy - were too wide and elusive. It did not provide any clear objective against which performance could be measured. Mandating multiple missions might also weaken the consistency of KIC's investment management. Measures to promote the onshore asset management industry - an integral part of the Presidential Committee's vision to transform Seoul into Northeast Asia's niche financial hub - could also harm KIC's investment returns if assets were entrusted to onshore management firms with little track record. They urged to restate the mission as "maximizing international purchasing power, taking into account an acceptable level of risk." This was the exact same phrase suggested in the consulting report commissioned by the Presidential Committee.

Second, they raised concerns over the provisions that would have allowed KIC to incur debts and to make investments in KRW-denominated domestic assets. Under such an arrangement, KIC would be vulnerable to pressures to boost the domestic stock market or to manipulate exchange rate in the FX market. ${ }^{37}$ In particular, incurring KRW-denominated debts refuted the very rationale of its establishment. As laid out in the Presidential Committee's report, dated December 11, 2003, the government was establishing KIC to enhance the returns on its FX reserves, and thereby minimize the loss BOK was suffering from high KRW interest rates. Incurring further debts denominated in KRW would only make the matter worse. Also, investments in domestic assets can offset the effect of sterilization. That is, the contractionary effect of issuing KRW-denominated debt either by BOK or by the government can be offset by the expansionary effect of KIC purchasing domestic assets. They urged the law makers to prohibit KIC from incurring debt and from investing in domestic assets.

Third, they strongly argued that BOK, as an asset-entrusting owner, should have the exclusive right to make withdrawals and to impose restrictions on KIC's asset management. They discussed the practice followed in Singapore between the Monetary Authority of Singapore (MAS) and CIG. Accordingly, they suggested removing the provision in the bill that prescribed the investment management contract between asset-entrusting owners and KIC be determined by the Presidential Enforcement Decree.

Fourth, they raised concerns that the bill gave too much statutory power to the Minister of Finance and Economy, whose tasks it would have been to approve the Articles of Incorporation (AOI), nominate the KIC President candidate, and appoint the Directors and Auditor of KIC. They argued that such powers should be given to the Steering Committee. They also argued that detailed eligibility requirements for Civil Members and KIC President be stipulated in the Act instead of being delegated to the Presidential Enforcement Decree, which was de facto under the control of MOFE. Moreover, they suggested having

37 To purchase US dollars in the FX market, KIC would have to borrow in KRW. 
provisions related to subcommittees, compliance and investment ethics in the Act. On subcommittees, they proposed to establish an investment committee and a compensation committee composed of Civil Members of the Steering Committee. This is in contrast to the provision in the bill that allows the establishment of advisory committees composed of outside experts. To ensure the independence of the Civil Member Nomination Committee, the witnesses also suggested adding the speaker of the National Assembly or the Chairperson of the Finance and Economy Committee to the list of persons eligible to appoint Nomination Committee members.

Fifth, they criticized the level of transparency the bill prescribed. In particular, they pointed out the problem of giving KIC the power to veto the National Assembly's disclosure of KIC-related non-public information. Instead of granting KIC such discretionary veto power, they argued for adding a provision in the Act listing the items that should not be publicly disclosed. Other items, they argued, should be fully disclosed to ensure effective outside monitoring.

Sixth, they criticized the creation of KIC Establishment Committee as provided in the bill's addendum, which required this Committee to assume two important tasks before KIC's official launch. One was that the Committee recommend the KIC President Candidate to the Ministry of Finance and Economy, and the other was that it prepare the Articles of Incorporation for approval by the Minister of Finance and Economy. The witnesses expressed concern that this Committee might significantly weaken the role of the KIC Steering Committee, so they suggested that the Steering Committee should be created first and then ask it to recommend the candidate for KIC President and approve the Articles of Incorporation.

Between December, 2004 and February, 2005, the Finance and Economy Committee revised the bill, taking into consideration the criticisms raised at the public hearing. Important revisions made to the bill included the following:

- Modification of the mission statement slightly, dropping the idea that KIC should contribute to the nation's economy in favor of promoting the advancement of the financial industry.

- Removing the provision empowering the Minister of Finance and Economy to approve KIC's Articles of Incorporation, giving that right instead to the Steering Committee.

- Addition of provisions stipulating the eligibility requirements of Steering Committee Civil Members, ${ }^{38}$ the KIC President, ${ }^{39}$ the $\mathrm{CIO},{ }^{40}$ and the auditor. ${ }^{41}$

${ }^{38}$ On the expertise requirement, Civil Members must either be (i) a person employed at a university or research institute and whose research experience in finance or investment is 10 or more years, (ii) a person with 10 or more years of experience in investment management at international financial organizations or 
- Revamping the composition of the Civil Member Nomination Committee such that it would now be composed of six members, each appointed by head of organizations stipulated in the Act. The organizations include (i) a finance-related academic association determined by the Presidential Enforcement Decree, ${ }^{42}$ (ii) the Asset Management Association of Korea (AMAK), (iii) the Korea Federation of Banks (KFB), (vi) the Korea Life Insurance Association (KLIA), (v) the Korea Securities Dealers Association (KSDA), and (vi) the Korean Institute of Certified Public Accountants (KICPA). ${ }^{43}$ This was closer to the original draft prepared by MOFE in June 2004. Given the influence MOFE has over these trade organizations, it is doubtful that the Nomination Committee could be independent from MOFE.

- Establishment of a committee to nominate the President of KIC, to be composed of Civil Members of the Steering Committee and members each appointed by organizations that have entrusted assets to KIC above the threshold specified by the Presidential Enforcement Decree. ${ }^{44}$ According to the revised bill, the Chairman of the Nomination Committee must be selected from the pool of Civil Members.

- Specific provisions directing KIC to adopt internal control standards and to appoint a compliance officer whose nomination must be approved in advance by the Steering Committee.

- Deletion of provisions allowing the investment management contract between KIC and the entrusting organizations to be dictated by the Presidential Enforcement Decree. In effect, the contract became a voluntary one to be negotiated between the two parties.

- A requirement that assets entrusted by different organizations be kept in separate accounts.

- Specification of management fees, payment procedures, and that the form of such payment should be negotiated between KIC and the entrusting organization.

\footnotetext{
domestic/overseas financial institutions of more than a certain size set forth by the Presidential Enforcement Decree, or (iii) an attorney-at-law or a certified public accountant with10 or more years of experience in finance, investment or company auditing. The revised bill also bans employees of asset entrusting organizations from being appointed as Civil Members of the Steering Committee. The revised bill also imposes a three-year cooling period, during which KIC retirees cannot serve as Steering Committee Civil Members.

39 The KIC President must have 10 or more years of experience in either finance or investment related areas.

40 The CIO must have 10 or more years of experience in investment management at international financial organizations or domestic/overseas financial institutions of more than a certain size set forth by the Presidential Enforcement Decree

${ }^{41}$ Auditor must either be (i) a person with 10 or more years of experience in finance or investment related areas, or (ii) a certified public accountant (CPA) with 10 or more years of experience in corporate auditing.

42 The Decree later names the Korea Money and Finance Association to be the academic association that can nominate Civil Member Nomination Committee members.

${ }^{43}$ With the merger between AMAK and KSDA in 2009, the nomination is now carried out by the Korea Financial Investment Association (KFIA).

${ }^{44}$ The Decree later set the threshold to be 1 trillion KRW (approximately, 1 billion US dollars). 
- A ban on investment in KRW-denominated domestic assets. Specifically, it stated that KIC, in principle, must manage its entrusted assets only in those denominated in foreign currencies. If KIC manages KRW-denominated assets temporarily for an unavoidable reason, it must be either in the form of bank deposits or passively held public debt.

- Banning KIC the right to issue debt.

- Stipulation of the items that must be disclosed by KIC. According to this revision, KIC must disclose (i) the financial statements of KIC and the accounting rules used, (ii) the auditors' report, (iii) investment policy statement approved by the Steering Committee, (iv) the total assets under management, (v) the overall investment performance, (vi) asset allocation weights and performance of each asset class set forth by the Presidential Enforcement Committee, and (vii) changes in its fund managers. ${ }^{45}$

- Lastly, the revised bill removed the provision giving KIC the power to veto the National Assembly's disclosure of KIC-related non-public information. It granted the National Assembly the right to disclosure such information provided that it is approved by the standing committee overseeing KIC.

The bill passed the plenary session on March 24, 2005, and took effect from July $1^{\text {st }} 2005$.

\section{III.EVOLUTION}

\section{Evolving Views on KIC's Mission}

As mentioned earlier, the official mandate of KIC can be found in the Korea Investment Corporation Act. In Article 1, the Act states that KIC is to conduct efficient management of assets which are entrusted by the Government, the Bank of Korea, and other sources, and thereby contribute to the development of Korea's financial industry. Neither the Act nor its enforcement decree make any further effort to clarify what exactly "efficient management" means or what constitutes "the development of the financial industry." Such vague mission statement can give rise to two possibilities. One is that KIC's mission can change over time. Another is that it can have multiple missions. Both are problematic. Under such circumstances, the institution cannot have a well designed investment policy statement (IPS), and managers subject to that can lose their sense of direction, ultimately damaging its performance. In this

${ }^{45}$ It is not clear why the Finance and Economy Committee introduced a provision that requires KIC to disclose the name of its fund managers. To meet this requirement, KIC in practice discloses the names of its internal fund managers. KIC, however, does not disclose the names of its external managers, nor does it disclose those of its custodians. 
sub-section, I go over how policy makers' views of KIC's mission evolved over time.

\section{Countermeasure against Capital Inflows}

As discussed in the previous section, the idea behind KIC first emerged as a tool to address the problem related to surges of capital inflows. The outbreak of a currency crisis triggered a huge capital outflow. In November and December of 1997, Korea experienced a financial account deficit of 10.5 billion US dollars. Withdrawals of dollar loans from Korean banks accounted for 99 percent of the outflow. But the foreign exchange shortage soon switched to a surplus. First of all, the weak currency value and the collapse of domestic demand contributed to a huge current account surplus: 42.6 billion US dollars in 1998 and 24.5 billion US dollars in 1999. Consequently, the KRW-USD exchange rate that peaked at 1,964.8 on December 24, 1997 was already down to 1,155.90 by the end of June 1999.

The pressure on the exchange rate strengthened in the $4^{\text {th }}$ quarter of 1999 as the financial account also switched to a surplus. The successful debt restructuring of Korean banks' short-term external debt in January 1998 slowed down the withdrawal of bank loans thereafter. ${ }^{46}$ The fire sale of Korean firms to foreign purchasers also increased foreign direct investments. The successful corporate debt restructuring of the Daewoo group - the $4^{\text {th }}$ largest conglomerate as of 1996 - by the end of 1999 , also triggered foreign portfolio investments. ${ }^{47}$ Consequently, in the $4^{\text {th }}$ quarter of 1999 , Korea's financial account recorded a 6 billion US dollar surplus. In the following quarter, the surplus increased to 9.6 billion US dollars. $<$ Figure $2>$ shows a bar chart of monthly financial account surpluses during July 1997 and March 2000.

In the face of this sudden shift to a FX surplus, the Korean government intervened heavily in the foreign exchange market and accumulated foreign exchange reserves. The reserve, which was only 20.4 billion US dollars in December 1997 - to be exact, 4 billion US dollars on December 18, 1997 - reached 74 billion US dollars by the end of 1999. < Figure 3> shows a bar chart of monthly FX reserves from January 1997 to March 2000. The Korean government's market intervention was justified on many grounds. First, accumulating reserves was the key to restoring confidence among international investors. Moreover, the accumulation of reserves was inevitable to later pay back the Korean government's disbursements from the IMF under the stand-by agreement and loans from the World Bank. Third, the KRW-USD market at that time was too thin to handle large foreign exchange transactions. Without smoothing operations, it was obvious that the exchange rate could be easily misaligned from its fundamentals.

46 For a detailed account of Korean bank's short-term debt restructuring, see Kim and Byeon (2002).

47 For a detailed account of Korea's corporate restructuring during 1998-2001, see Mako (2002). 
Between current account and financial account surpluses, policymakers in Korea were particularly concerned with the latter because surges of capital inflows would appreciate the domestic currency and then deteriorate the current account balance. The currency crisis in 1997 clearly demonstrated that a sudden stop in capital inflows coupled with a current account deficit made the country extremely vulnerable. Against this policy dilemma, a foreign exchange market intervention appeared as the obvious solution for the policymakers. By purchasing dollars in the market, the government eased the downward pressure on the exchange rate, and thereby maintained the price competitiveness of Korea export products. Also, the accumulated foreign exchange reserve remained available for use later in time of crisis.

But, Korean policymakers understood that foreign exchange market intervention cannot be used for extended periods of time. They feared that trading partners might view it as exchange rate manipulation. Policymakers wanted a less controversial solution. One was encouraging residents to engage in overseas portfolio investment. If enough money is invested abroad, this will offset capital inflows and thereby ease the pressure on the exchange rate. In fact, in December 1999, the Ministry of Finance and Economy announced that it would exempt overseas portfolio investments from the capital gains tax. The government, however, did not achieve much in this regard. In 2000, the private sector's overseas portfolio investment amounted to only 0.5 billion US dollars

Against this backdrop, establishing a sovereign wealth fund dedicated for overseas investment appeared as an attractive alternative. One obvious merit is that government can force the fund to invest in overseas assets, while it cannot do so to private Korean investors. Since part of the foreign exchange reserve will have to be transferred to the fund, the reserve will accumulate much more slowly and thus engender less controversy.

\section{Greater returns on $F X$ reserve}

With the accumulation of foreign exchange reserves a new concern emerged. Since Korea sterilized most of its interventions, it issued huge amounts of KRW denominated debt - either monetary stabilization bonds or foreign exchange stabilization bonds - and the interest they had to pay was well above the interest earned on foreign currency reserves. This problem was aggravated with continued dollar depreciation against the Korean won. So, the government lost money on both interest and currency. Clearly, this represented a deviation from the interest parity condition, and it did not disappear for many

years; in the meantime, losses kept accumulating. ${ }^{48}<$ Figure $4>$ shows the yields on US Treasury notes $(2$

\footnotetext{
${ }^{48}$ There are two reasons behind this deviation. One is the near absence of foreigners in the Korean fixed income market. The other is heavy FX market intervention combined with sterilization, which effectively absorbed the downward pressure on domestic interest and exchange rates.
} 
year) and monetary stabilization bonds (2 year) during March 1999 - December 2003.

By 2003, the issue was well understood even among politicians. Members of the National Assembly questioned whether the amount of reserve was excessive. Related to this, in April 2003, the Ministry of Finance and Economy reported that the accumulated loss from its Foreign Exchange Stabilization Fund was 2.4 trillion Korean won (approximately, 2 billion U.S. dollars) as of December 2002. ${ }^{49}$ Given that the Foreign Exchange Stabilization Fund constitutes only a part of total reserves, the accumulated loss must have been much greater. ${ }^{50}$ Of course, maintaining a high level of reserve brings about a number of intangible benefits. It restores confidence among international investors, it allows Korean banks to borrow at a lower rate, and it ultimately prevents future currency crises. Such benefits certainly outweigh the losses that were reported. Nevertheless, criticism continued.

Against this backdrop, the idea of setting up a sovereign wealth fund emerged again. If part of excess reserves is entrusted or transferred to the fund, and if the fund seeks more lucrative investments, the government can stop the loss from mounting. A long investment horizon and a greater risk appetite would allow the fund to invest in riskier and less liquid assets, which would normally generate higher returns. Such thoughts certainly occurred to lawmakers when they passed the Korea Investment Corporation Act in March 2005. The phrase "efficient management" that appears in Article 1 of the Act meant to say this in a crude way.

\section{Seoul as Northeast Asia's Financial Hub}

In December 2003, the Presidential Committee on the Northeast Asia Business Hub and MOFE released a joint report that proposed the establishment KIC. The newly added rationale was to use KIC as a vehicle to attract foreign asset management companies to Seoul, and thereby transform Seoul into Northeast Asia's financial hub. It suggested that KIC give mandates to foreign asset management companies and induce them to relocate in Seoul. This is precisely the measure Singapore took in 1998. As mentioned earlier, GIC and MAS earmarked 35 billion SGD (approximately 19 billion USD; 25 billion SGD from GIC and 10 billion SGD from MAS) to be placed out to external managers, regardless of nationality, over three years till 2000. They were hoping that this would act as seed money to grow the Singapore fund

\footnotetext{
49 This fund issues KRW-denominated bonds and purchases dollars using the Korean won it financed. It then deposits the dollars at the Bank of Korea (BOK). In 2002, the coupon rate on the foreign exchange stabilization bond was $8.0 \%$, while the deposit rate at BOK was only $2.7 \%$. Korean won also appreciated in 2002 by $10 \%(1326.1 \rightarrow 1200.4)$. The fund's dollar deposits at BOK also constitute the total foreign exchange reserve.

${ }^{50}$ Since foreign exchange stabilization bond is a government bond, its issues requires approval from the National Assembly. Monetary stabilization bond, which is issued by BOK, on the other hand, is not a government bond, and its issuance therefore is not subject to National Assembly's approval.
} 
management industry.

The Korea Investment Corporation Act states, in Article 1, that KIC is to conduct efficient management of assets which are entrusted by the Government, the Bank of Korea, and others, and thereby contribute to the development of financial industry. The asset management industry was certainly the key financial industry the lawmakers had in mind when they passed the Act in March 2005.

\section{Preventing a FX Liquidity Crisis}

Many countries were hit hard by the global financial crisis of 2008. Korea was no exception. With global liquidity quickly drying up, Korean banks failed to roll over their external debt, the value of Korean won nose-dived against the U.S. dollar, and the size of foreign exchange reserves plummeted in the course of intervention. The KRW-USD exchange rate peaked on March 3rd 2009 at 1,573.60, and reserves dropped by 63.7 billion US dollars over a seven months period (March-November 2008). $<$ Figure 5> shows how the KRW-USD exchange rate and the reserves evolved during the crisis period.

At first glance, the reason behind the acute crisis hardly differs from that Korea experienced during the Asian crisis back in the late 1990s. Korean banks had a huge external - mostly short-term — debt. With a second look, however, fundamental differences between the two crises emerge. Back then, local problems largely drove the crisis. This time, the crisis originated outside of Korea, triggered by problems in other countries. The nature of excessive short-term dollar borrowing is also quite different. Back then, it was to make loans to Korean corporations. This time, it was to square the long dollar positions Korean banks entered when they purchased dollars forward from Korea ship manufacturers and Korean overseas portfolio investors. ${ }^{51}<$ Table $1>$ reports the volume of dollar forwards sold during the pre-crisis period. FX risk management using FX derivatives sat at the heart of the crisis.

Local branches of foreign banks in Seoul did their part to exacerbate Korea's external debt situation - another compelling feature of the recent crisis. Even when Korean banks could no longer borrow at competitive rates during the U.S. subprime mortgage crisis in 2007, foreign bank branches in Seoul supplied dollars at cheap rates through FX swaps. ${ }^{52}$ Since these branches financed the dollars from their parent banks, Korea's external debt soared. ${ }^{53}<$ Figure $6>$ and $<$ Figure $7>$ show the level of Korea's external debt. When the crisis hit, not only Korean banks, but also foreign banks in Seoul had to pay back

${ }^{51}$ See Appendix 2 on how dollar borrowing can hedge FX risk when a bank has a dollar forward position in its balance sheet.

${ }^{52}$ Dollars were also provided in the form of currency return swaps (CRS). CRS transactions defer from FX swap transactions in two ways: the maturity is longer (more than a year) and it involves an exchange of interest income.

${ }^{53}$ Foreign banks' Seoul branches are considered residents in balance of payments accounting. 
what they had borrowed. This meant that FX swaps could no longer be rolled over. Korean banks had to pay back not only their direct dollar loans, but also the funds they had borrowed from the local branches of the overseas banks. Appendix 1 summarizes the nature of the 2008 FX liquidity crisis.

Against this backdrop, the idea emerged to use KIC as a substitute for the expedient borrowing from the foreign banks in Seoul, i.e., letting KIC enter FX swaps with Korean banks, thereby eliminating the role played by the foreign bank branches. Since KIC does not need to finance dollars externally, Korea's external debt would not increase and therefore would be less vulnerable to external shocks. To date, no official statement was made by the government on this idea. But, it was mildly suggested in the press release (dated June 14 2010) made by the Ministry of Strategy and Finance (MOSF) when announcing measures to limit capital flow volatility. ${ }^{54}$ In the press release, the Ministry made it clear that it would increase KIC's assets under management (AUM) to 50 billion US dollars by 2015 and, if necessary, use it as a source of FX liquidity. ${ }^{55}$ No details, however, were provided. Prior to this press release, a number of newspapers speculated that KIC would enter the FX swap market and replace the role played by foreign bank branches. ${ }^{56}$ By August 2010, it became evident that some institutions outside the government also shared this view. One private think tank released a report proposing that KIC enter the FX swap market. ${ }^{57}$ The Presidential Council on National Competitiveness, chaired by the former Minister of Strategy and Finance, further urged in January 2011 that the National Assembly pass the bill revising the Korea Investment Corporation Act, which would allow KIC to hold KRW-denominated assets, a necessary condition for KIC to enter the FX swap market.

This new arrangement may have two other benefits. First, KIC may be able to profit from arbitrage opportunities. During the pre-crisis period (2007 2H - 2008 1H), the KRW-USD exchange rate deviated substantially from the covered interest parity (CIP) condition. The interest differential (domestic - foreign) was on average higher than the swap rate $(\mathrm{F} / \mathrm{S}-1)$ by $200 \mathrm{bp}$. This allowed foreign bank branches in Seoul to profit from USD carry trading that involves FX swap (spot sell \& forward buy) transactions with Korean banks. $<$ Figure $8>$ and $<$ Figure $9>$ depict this deviation during 2008-2009. Second, since KIC will be holding KRW, instead of USD, once it enters FX swap agreements, Korea's foreign exchange reserve will drop, which may mitigate two concerns with regard to hoarding reserves: the opportunity cost of holding low interest dollar assets and the suspicion of exchange rate manipulation raised by trading

\footnotetext{
54 In 2008, the Ministry of Finance and Economy was renamed as the Ministry of Strategy and Finance.

55 At the time of this writing (June 2011), it is already expected that KIC's total assets under management would surpass 50 billion US dollars by the end of 2011.

56 See E-Daily (February 25, 2010 and July 19, 2010). MOSF, however, officially released a commentary stating that the Ministry has never deliberated such an arrangement.

57 The report by Jeong and Jung (2010) was issued by Samsung Economic Research Institute (SERI).
} 
partners.

A number of concerns arose, though, over this idea. First, a foreign exchange liquidity crisis is now less likely thanks to a number of policy measures taken by the government in recent years. In June 2010, the Ministry of Strategy and Finance announced that it will impose a limit on banks' (including branches of foreign banks in Seoul) FX forward positions. The limits are 50\% and 250\% of equity capital for Korean banks and foreign bank Seoul branches, respectively. This measure will limit the amount of FX swap transactions between the two, and thereby lower the level of Korea's external debt. Moreover, in December 2010, the Korean government announced that it would impose a "Macro-prudential Stability Levy" on non-deposit foreign currency liabilities. This was announced a month after the G20 Seoul Summit where the leaders agreed on the need for design and implementation of special macro-prudential procedures to curb excessive capital flows. The measure has four key features: (i) the Levy will be charged on "non-deposit foreign currency liabilities" that appears in bank balance sheets; (ii) the Levy will first apply to banks including domestic banks and foreign bank branches; (iii) the Levy rate will vary according to debt maturity; (iv) the Levy will be collected in foreign currency and later used in times of crisis to stabilize the financial market. With such a policy in place, there will be less need to use KIC as a vehicle to prevent FX liquidity crises.

Another concern arose with particular regard to a potential moral hazard problem. Since KIC will continue rolling over its FX swap agreements even in times of FX liquidity crises, Korean banks may be ex ante less wary of their FX liquidity management. In essence, the new arrangement is no different from Bank of Korea directly providing dollar liquidity via FX swap in times of crisis. If this is known ex ante, the same kind of moral hazard problem may arise.

Lastly, there is an argument that the root cause of excessive FX swap transactions is government's intervention in the spot market combined with sterilization (Song, 2010). Intervention may have slowed down the fall of the KRW-USD exchange rate and sterilization may have slowed down the fall of the domestic interest rate. This may have caused the continued deviation from covered interest parity and lured in more FX swap transactions between foreign bank Seoul branches and Korean domestic banks. Such a diagnosis calls for less FX market intervention, and if this is sufficient to lower the volume of FX swap transactions, there may be no role for KIC to play.

\section{Operations and Portfolio Management}

\section{Operations}

Immediately after the passage of the KIC Act, MOFE established two divisions - the Financial Hub Planning Division and the Financial Hub Cooperation Division - in the Ministry that will carry out the 
tasks concerning creation of the Northeast Asia financial hub. Also, pursuant to the KIC Act, MOFE formed the KIC Establishment Committee, which carried out certain tasks prescribed in the Act. ${ }^{58}$ In the absence of the Steering Committee, it recommended the KIC President candidate to the Minister of Finance and Economy. It also prepared KIC's first Articles of Incorporation (AOI), which were approved by the Minister of Finance and Economy on June 30, 2005. ${ }^{59}$ On the exact same day, the President also approved the Presidential Enforcement Decree of the KIC Act. MOFE's investment of 100 billion KRW (approximately 100 million USD when using the KRW-USD exchange rate of 1,000) as KIC's paid-in capital also took place on June $30{ }^{60}$ KIC was ready for its official launched on July $1^{\text {st }} 2005$.

Just before the official launch of KIC, the President also designated Dr. Kang-Won Lee (July 2005 - July 2006) as the first President of KIC. He was as a former CEO of a major commercial bank, a major securities firm, and a major asset management company. In July, the Minister of Finance and Economy also appointed the first Auditor of KIC. Mr. Hongchul (Hank) Ahn (July 2005 - June 2008), however, was a former bureaucrat of MOFE. The popular press criticized MOFE for using KIC as a vehicle to secure new positions outside the Ministry for its retired bureaucrats. In August, the President appointed six Civil Members of the Steering Committee. Dr. In-June Kim (August 2005 - June 2008), professor of economics at Seoul National University, served as the fist Chairman. But, it was not until February 2006 that KIC was able to appoint its first Chief Investment Officer (CIO). Dr. Guan Ong held various senior investment positions for Prudential in Hong Kong (Portfolio Manager), Singapore (Senior Portfolio Manager), and Korea (CIO/CEO).

The investment management contract with BOK was concluded in June 2006. BOK pledged to entrust 17 billion US dollars by the first quarter of 2007. MOFE - its Foreign Exchange Stabilization Fund, to be exact - also entered into a contract with KIC in October pledging 3 billion US dollars. BOK, however, imposed a restriction that prescribes the assets entrusted by BOK be managed in a way that meets the definition of international reserves. ${ }^{61}$ This meant that assets entrusted by BOK cannot be used

\footnotetext{
58 The Committee was composed of seven members: Vice Minister of Finance and Economy (chair) and members appointed by the six organizations that also appoint the members of the Civil Member Nomination Committee. The names of the KIC Establishment Committee members, however, have never been disclosed to public.

59 KIC's Articles of Incorporation must be approved by the Steering Committee. The exception is the very first AOI. Pursuant to the KIC Act Addendum, the first AOI is approved by the Minister of Finance and Economy.

${ }^{60}$ Funding was made possible through the Foreign Exchange Stabilization Fund administered by MOFE. The KIC Act limits KIC equity capital at 1 trillion KRW (approximately 1 billion USD).

61 The fifth edition of the IMF Balance of Payments Manual (BPM5), a country's international reserves refers to "those external assets that are readily available to and controlled by monetary authorities for direct financing of payments imbalances, for indirectly regulating the magnitude of such imbalances through intervention in exchange markets to affect the currency exchange rate, and/or for other purposes." 
for investments in private firms. ${ }^{62}$ Investments in alternative assets had to be exclusively financed from the Foreign Exchange Stabilization Fund. According to the Presidential Enforcement Decree, BOK can withdraw from KIC if (i) the size of FX reserve fell by more than $10 \%$ for two consecutive months, (ii) if Korea's sovereign rating fell below investment grade by two or more international credit rating agencies headquartered either in the US or in UK, or (iii) if KIC breached the investment management contract and did not rectify such breach within 30 days. With the initial installment of funds from BOK, KIC launched its global fixed income investment in November 2006.

Since its inception, KIC has had three CEOs. The first two, however, did not serve their three-year term. The first CEO, Dr. Kang-Won Lee, stepped down from his position having served only for one year. He was prosecuted for multiple accusations related to his work at Korea Exchange Bank (KEB) where he served as CEO before joining KIC. In October 2010, the Supreme Court released its final verdict sentencing him to 18-months' imprisonment and levying upon him a fine of 150 million KRW for making slush funds and taking bribes. The second CEO, Serck-Joo Hong, served only for two years. His replacement has to do with Korea's practice of replacing the heads of public institutions during the first year of a new national Presidency, in this case, an event triggered by President Myung-Bak Lee's inauguration in February 2008. The positions are often filled then with people who helped the new President win the election. According to one study, there were a total of 280 CEO replacements occurred in public institutions during a four-year period between May 2006 and April 2010. ${ }^{63}$ But, 45\% of the replacements took place over a six-month period between May 2008 and October 2008. Many CEOs had to step down before their term expired. The third CEO, Young-Wook Chin, served three full years. But his appointment was criticized as he was a former bureaucrat who worked at MOFE for many years.

The appointment of KIC Auditors also raised concerns. Among the three who have served as KIC Auditors, only two are known to public. Even if one visits KIC's homepage, carefully reads its annual reports, or conducts an extensive news article search, the second Auditor cannot be identified. Moreover, the first (Ahn, Hongchul) and the third Auditors (Kang, Hyung-Wook) are both former bureaucrats who have worked extensively at MOFE. This confirms BOK's earlier accusation that KIC might be used as a vehicle to secure outside positions for retiring bureaucrats.

The appointment of first CIO proved similarly dubious. During the inspection of state affairs in October 2006, Sang-Jung Shim, a member of the National Assembly, questioned whether Guan Ong met the expertise requirement prescribed in the KIC Act. She claimed that his investment management

${ }^{62}$ According to BPM5, securities should include highly liquid, marketable equity and debt securities. Liquid, marketable, long-term securities (such as 30-year U.S. Treasury bonds) are included. Nonissued securities (that is, securities not listed for public trading) are excluded.

${ }^{63}$ See Kim (2010b). 
experience spanned only 8 years (1998-2006), falling short of the 10-year minimum set forth by the KIC Act. No concerns have been raised against the second CIO, Scott Kalb, who had been a hedge fund manager at Tudor Investment Corp. He also served as managing director at Citigroup's Smith Barney International Asset Management.

Since its inception, KIC's Steering Committee has had three Chairs. The first, In-June Kim served his first term in full, but had to step down in mid 2008 in the middle of his second term. Note that Civil Members of the Steering Committee have a two-year term. His departure again has to do with Korea's practice of replacing the heads of public institutions during the first year of a new Presidency. The second Chair (Yoon-Dae Euh) was a former President of Korea University, from which President Myung-Bak Lee graduated. Dr. Euh was actively involved in the Presidential election. Dr. Euh, however, stepped down from his position after a year. A year later, in June 2010, Dr. Euh was elected CEO of KB Financial Group. Dr. Ke-Sop Yun assumed the Chair position in September 2009. He was a professor of finance at Seoul National University.

The KIC Steering Committee formed a number of subcommittees. As of December 2010, it has two standing subcommittees - Investment and Risk Management - and two non-standing committees Budget Review and Management Compensation. Each subcommittee is composed of four Civil Members. Pursuant to the Act on Public Institutions Management, KIC is required to disclose it executives' annual salaries and the minutes of its Board meetings. ${ }^{64}$ The CEO received 480 million KRW (approximately 480,000 US dollars) each year during 2006-2007. In 2008, the pay level dropped down to 161 million KRW (approximately 161,000 US dollars). This was due to MOSF's new policy to lower executive pay in public institutions. During 2009-2010, the level of pay returned almost to its original level. The CEO was paid 467 and 391 million KRW, respectively, in 2009 and 2010. KIC also discloses its Auditor's salary 340 million KRW (approximately 340,000 US Dollars) each year during 2006-2007. In 2008, the pay level dropped down to 129 million KRW (approximately 129,000 US dollars). During 2009-2010, his level of pay also bounced back. The Auditor received 232 and 252 million KRW, respectively, in 2009 and 2010. KIC, however, does not disclose the pay package for its CIO.

Pursuant to the Act on Public Institutions Management, KIC discloses its Board meeting minutes, although the level of disclosure is minimal: they only disclose agenda titles. No underlying documents are attached, nor are any substantive discussions revealed. In the case of Steering Committee meetings, KIC does not even disclose its agenda items.

During fiscal year 2010, KIC earned an aggregate investment management fee of 74.5 billion KRW,

${ }^{64}$ They are available via www.alio.go.kr (in Korean). 
which is approximately 67 million US dollars (using the exchange rate of 1,100 KRW/USD). Given that the total size of entrusted assets is 36.9 billion US dollars, as of December 2010, the average investment management fee can computed to be approximately 18 basis points $(0.18 \%)$, which seem reasonable, given that KIC does not engage in any fundraising activities and that $87.7 \%$ of its assets are invested in public securities. $^{65}$ In addition, KIC re-entrusts $30 \%$ of its entrusted assets. Thanks in part to this management fee, KIC has been recording positive net income since 2008. ${ }^{66}$ During 2009-2010, it also paid out cash dividends to MOFE (20\% dividend payout ratio).

As of December 2010, KIC has three divisions (Investment Management, Corporate Management, and Risk Management), one overseas office (New York), and employs 85 people. The Investment Management Division is headed by the CIO who oversees the Investment Strategy Team, the Public Markets Group, and the Private Markets Group. The Auditor heads the Audit Unit and appoints the external auditor. Samil PricewaterhouseCoopers has been KIC's external auditor since 2006.

\section{Portfolio Management}

As of December 2010, the total assets under management are 37.5 billion US dollars. This ranks KIC the $19^{\text {th }}$ largest sovereign wealth fund (SWF) in the world. Among SWFs with non-commodity origins, it is the $8^{\text {th }}$ largest. According to the government, KIC's total assets under management will be increased to 50 billion US dollars by 2015.

Pursuant to the KIC Act, KIC discloses its Investment Policy Statement (IPS). ${ }^{67}$ Despite the mission statement in the KIC Act, the IPS of KIC states that it should achieve a stable and continuous return exceeding the benchmark within an appropriate level of risk. Benchmarks are disclosed in KIC's annual report. ${ }^{68}$ Other than that, the IPS does not give much useful information. There is no discussion about KIC's risk tolerance level, nor does it give out strategic asset allocation (SAA) weights. The IPS discusses tactical asset allocation (TAA) and portfolio rebalancing, but does not give out any information on its tolerance bands. The level of disclosure is so poor that it raises the concern that KIC is in breach of

${ }^{65}$ The size of total entrusted assets is slightly smaller than the size of total assets under management.

${ }^{66}$ Net incomes were -5.1 billion KRW (2006), -3.1 billion KRW (2007), 10.2 billion KRW (2008), 27.9 billion KRW (2009), and 16.3 billion KRW (2010). The drop in net income in 2010 is related to the fact that KIC started to make investments in alternative assets. Cash dividends to MOFE were 5.6 billion KRW in 2009 and 3.3 billion KRW in 2010.

${ }^{67}$ Detailed information on KIC's governance structure, operations, and investment policy can be found from its homepage (www.kic.kr/en).

${ }^{68}$ Morgan Stanley Capital International All Country (unhedged) for equities, Barclays Capital Global Aggregate (unhedged) for bonds, Barclays Capital Global Inflation-linked for inflation-linked bonds, S\&P GSCI Light Energy for commodities, and G7 inflation $+5 \%$ for other alternative assets (hedge fund, private equity, and real estate). 
the KIC Act. Also, it undermines the very reason why the National Assembly revised the bill and explicitly prescribed KIC to disclose its long-term investment policy statement. The idea was to allow the general public to monitor the operations of KIC, but with the current level of disclosure, such purpose cannot be served.

Actual asset allocations and investment performances are disclosed in KIC's annual report. < Table $2>$ shows the allocations, as of December $2011.87 .7 \%$ of the assets are allocated in public securities: $41.8 \%$ in public equities and $45.9 \%$ in public bonds. Alternative assets take up 5.6-9.2\%, depending upon whether or not one classifies KIC's Special Investments in the alternative asset class. Special Investments include KIC's direct exposure to strategically chosen industry sectors, such as energy and finance. All other alternative asset class investments are carried out by external managers. One issue regarding KIC's asset allocation is that its weight on public bonds may be considered to be too large. If the purpose of setting up KIC was to improve the returns on Korea's entire FX reserve, KIC's investment in public bonds does not serve the purpose at all. Investments in corporate bonds take up only $17.7 \%$ of KIC's exposure to public bonds. ${ }^{69}$

$<$ Table 3> reports KIC's investment performance on traditional assets. Since inception, its excess return over benchmark is $-0.07 \%$ p. If one takes into account its performance on special investments, where it made a huge loss, the performance might be even worse. Although it is premature to assess KIC's long-term investment performance, it is certainly not impressive. The level of performance disclosure is also poor. First, it is not clear whether the returns are net of fees. Second, it does not disclose the performance on its alternative investments. No discussion is found in the annual report on fair value pricing. Third, KIC no longer reports investment performance separately for each asset class. During 2007-2009, KIC used to report the performance on equity and fixed income separately, but it stopped doing so in 2010. This is related to the way the Presidential Enforcement Decree defines asset classes. Instead of using the classifications familiar in the industry, the Decree lists securities, deposits, real estate, and others as separate asset classes. So, de jure, KIC is not in breach of the KIC Act. But, in spirit, it is clearly in breach. Fourth, there is no attribution analysis, nor is there any discussion about the level of risk KIC is taking.

Until August 2007, all the investments of KIC were carried out by external managers. In-house management, however, steadily increased. ${ }^{70}$ As of December 2010, internal management takes up 70.7\%

${ }^{69}$ Government bonds, securitized bonds, and agency bonds respectively take up 45.9\%, 20.5\%, and $15.9 \%$.

70 In-house management of global fixed income investment started in August 2007. The in-house management of global equity investment started in March 2008. 
of the traditional portfolio. ${ }^{71}$ This has considerably alleviated the problem of re-entrustment that effectively makes BOK pay management fee twice: one for KIC and another for KIC's external managers. This new emphasis on internal management, however, is in conflict with the idea of attracting foreign asset management companies into Seoul by hiring them as KIC's external managers. Also note that KIC does not disclose the list of its external managers, nor does it disclose its global custodian. Instead, it reveals only the names of its internal fund managers, clearly a result of the careless drafting of the KIC Act that prescribes KIC to disclose changes of its fund managers. KIC interpreted this as disclosing the names of each internal fund manager.

In its annual report, KIC briefly discusses how it exercises its voting rights. The annual report states that KIC has drawn up related procedures to ensure voting rights are exercised appropriately, but KIC does not disclose its proxy voting guidelines, nor does it disclose the related procedures. Moreover, the annual report states that KIC's basic policy is to maintain a neutral stance for holdings of less than $1 \%$ or in the case of externally managed investments.

Among the KIC's Special Investments, the most noteworthy is its 2 billion US dollars acquisition of Merrill Lynch preferred stocks back in January 15, 2008. KIC was joined by two other investors: Kuwait Investment Authority and Japan's Mizuho Financial Group. Also, Temaseck Holdings was the largest shareholder of Merrill Lynch, holding 9.6\% of common shares. This was the time when herds of sovereign wealth funds sought to acquire ailing US banks. They were betting that the US would soon recover from its subprime mortgage crisis, which proved to be wrong.

More specifically, KIC purchased mandatory convertible preferred stocks with a $9 \%$ dividend yield that was scheduled to be converted to $38,160,000$ shares of common stock in October $15,2010{ }^{72}$ KIC projected that the conversion would give KIC a 3\% stake in Merrill Lynch. As market conditions worsened, Merrill Lynch continued to take write-downs and losses. As of July 25, the common share price fell down to 27.5 dollars. Pursuant to the price reset clause, this prompted KIC to renegotiate the conversion terms with Merrill Lynch. On July 28, KIC announced that it converted its preferred shares into 72,243,217 common shares of Merrill Lynch and also received a dividend worth of 30 million US dollars, an inevitable move to minimize the loss. At the time of conversion, preferred shares were worth only 1,473 million US dollars for KIC. ${ }^{73}$ Conversion made its investment worth 2,138 million US

\footnotetext{
${ }^{71}$ If we assume that special investments (3.7\%) are internally managed and all other alternative assets $(5.6 \%)$ are externally managed, the fraction of internal management drops slightly down to $69.8 \%$.

${ }^{72}$ The conversion price is, in effect, 52.4 US dollars $(=2,000,000,000$ US dollars / 38, 160,000).

731,017 million USD worth of common stocks $(38,160,000$ shares X 26.65 dollars $)+397.5$ million USD of dividend expected until October $2010+58.5$ million USD of dividend $\mathrm{KIC}$ already received $=1,473$ million USD.
} 
dollars. ${ }^{74}$ Continued turmoil led Merrill Lynch to be taken over by Bank of America (BOA). In an allstock transaction, each Merrill Lynch common share was exchanged for 0.8595 shares of BOA. This deal valued Merrill at 29 dollars a share, which represented a 70 percent premium. By the end of 2010, BOA's share price fell down to 13.23 dollars. If KIC still holds 62 million shares, its investment is worth only 821 million US dollars. This is approximately a $54.5 \%$ loss over a three-year period. ${ }^{75}$ As of December 2010 , KIC holds only a $0.61 \%$ stake of BOA. ${ }^{76}$

In 2010, KIC made a number of cross-border acquisitions in the energy sector. In June, it made a 200 million US dollars investment in Chesapeake Energy Co., a US natural gas company. KIC purchased convertible preferred shares jointly with CIC and Temasek Holdings. ${ }^{77}$ In August, it made a 76.2 million US dollar investment in Laricina Energy, a Canadian thermal oilsands developer. KIC purchased 2.55 million common shares. ${ }^{78}$ In November, it made another investment in the oilsands sector. KIC made a 99 million US dollar investment in Osum Oil Sands Corp, purchasing 7.7 million common shares. ${ }^{79}$ Such investments can be considered sensible as they may help Korea suffer less from future oil shocks.

\section{Assessment against Global Standards}

KIC does not seem to be abiding by the Santiago Principles. ${ }^{80}$ First, according to Principle 2, the policy purpose of the SWF should be clearly defined and publicly disclosed and the pursuit of any other types of objectives should be narrowly defined and mandated explicitly. As mentioned earlier many times, KIC's mission statement is unclearly defined with multiple objectives. Second, according to Principle 6, the SWF's operational management should be conducted on an independent basis. Early dismissals of its executives and appointment of former bureaucrats are jeopardizing KIC's independent operation. Third, according to Principle 21, SWFs should publicly disclose its general approach to voting securities of listed companies, including the key factors guiding its exercise of ownership rights. Also, to dispel concerns about potential noneconomic or nonfinancial objectives, SWFs should disclose ex ante whether and how they exercise their voting rights. Moreover, to demonstrate that their voting decisions continue to

741,925 million USD worth of common stocks $(72,240,000$ shares X 26.65 dollars $)+30$ million USD of dividend +58.5 million USD of dividend KIC already received $=2,138$ million USD.

${ }^{75}$ [(821.5 million USD worth of common shock +88.5 million USD worth of pre-paid dividends $) /(2,000$ million USD worth of initial investment) $]-1=-0.545(54.5 \%)$.

76 Such holdings are not disclosed by KIC. This is based on the author's own calculation.

77 The conversion price is 27 dollars per share. Dividend yield is $5.75 \%$.

78 Since KIC does not disclose ownership percentage of company holdings, the figures are based on web search.

79 Again, the figures are based on web search.

${ }^{80}$ It is a code of conduct drafted by 27 IMF member countries with sovereign wealth funds in October 2008. It is also known as the Generally Accepted Principles and Practices (GAPP). 
be based on economic and financial criteria, SWFs could also make appropriate ex post disclosures. According to the same principle, SWFs are also expected to disclose their general approach to board representation. As mentioned earlier, KIC does not ex ante disclose its proxy voting guideline, nor does it make appropriate ex post disclosure of its proxy voting. Also, no policy has been disclosed by KIC regarding board representation.

According to the Sovereign Wealth Fund Institute, KIC scores 9 out of a perfect score of 10 in terms of its transparency. ${ }^{81}$ My own calculation, however, reveals that KIC should score $6 .{ }^{82}$ It should get 0 points on the following evaluation items: (i) Fund provides ownership percentages of company holdings, and geographic locations of holdings; (ii) fund provides total portfolio value, returns, and management compensation; (iii) fund provides guidelines in reference to ethical standards, investment policies, and enforcer of guidelines; and (iv) if applicable, the fund identifies external managers.

\section{IV.CONCLUDING REMARKS}

In this paper, I give a detailed account of the creation and the evolution of Korea Investment Corporation (KIC) - a sovereign wealth fund established in 2005 by the Korean government. In doing so, I highlight three of its unique features. First, the case of KIC effectively shows the problem of having an unclear mission statement, which allows the mission to evolve over time and multiple missions to coexist that may contradict each other. Second, it effectively reveals the typical conflicts that may arise between the central bank and the ministry involved when setting up a reserve-based sovereign wealth fund. Third, it effectively shows how much a sovereign wealth fund can be operated in a way that favors the bureaucrats and the politicians.

The paper also allows one to draw a number of policy recommendations for KIC. First, the Korea Investment Corporation Act should be revised to narrow down the scope of KIC's mission. A more focused mission statement would prevent KIC from deviating away from its original purpose. It also enables KIC to have an internally-consistent investment policy that can discipline its managers and also give them a sense of direction. Second, the Act or the Enforcement Decree should be revised so that KIC can be run in a much transparent way. For example, it should not leave out the details of its strategic asset allocation (SAA) when disclosing its investment policy statement (IPS). It should also disclose its investment performance separately for each asset class. When doing so, it should not use the classification

81 The index is named as the Linaburg-Maduell Transparency Index.

82 This is in line with the scores assigned by Truman (2011) and Behrendt (2011). Truman (2011) gives a score of 67 out of 100 when assessing against the Santiago Principles. According to his SWF scoreboard, KIC scores 60 out of 100. The Santiago Compliance Index computed by Behrendt (2011) is 62 out of 100 for KIC. 
that lumps up all securities in one asset class. Moreover, it should disclose the list of its external managers instead of its internal fund managers. Third, the investment management contract between BOK and KIC should be revised so that KIC can invest the entrusted funds in alternative assets. Otherwise, KIC cannot improve BOK's balance sheet and thus fail to fulfill one of its most important missions. Once KIC invests BOK-entrusted assets in alternative assets, they will be excluded from Korea's FX reserves.

\section{REFERENCES}

Behrendt, Sven (2011), "Sovereign Wealth Funds and Their Commitment to the "Santiago Principles" GEOECONOMICA Briefing April 2011

Clark, Gordon and Ashby Monk (2011), "Nation-state Legitimacy, Trade, and the China Investment Corporation" mimeo

Clark, Gordon and Ashby Monk (2010a), "Government of Singapore Investment Corporation (GIC): Insurer of last resort and bulwark of nation-state legitimacy," The Pacific Review 23(4): 429-451

Clark, Gordon and Ashby Monk (2010b), “The legitimacy and governance of Norway's sovereign wealth fund: the ethics of global investment," Environment and Planning 42(7): 1723-1738

Clark, Gordon and Ashby Monk (2010c), "The Norwegian government pension fund: ethics over efficiency," Rotman International Journal of Pension Management, 3(1):14-19

Jeong, Young-Sik and Dae-Sun Jung (2010), “Korea’s External Credit and Debt Imbalance,” SERI Economy Focus No.304 (in Korean)

Kim, Woochan (2010a), "Structural Issues in the Korean FX Market during the 2008 Global Financial Crisis: Empirical Investigation of FX Risk Management by Nonfinancial Public Firms," KDI Policy Study Series No. 2010-06 (in Korean)

Kim, Woochan (2010b), “The Governance of Public Institutions in Korea,” mimeo (in Korean)

Parrado, Eric (2004), “Singapore's Unique Monetary Policy: How Does it Work?” IMF Working Paper 04-10.

Song, Chi-Young (2010), “Excessive Foreign Capital Inflows and Pro-Cyclicality,” mimeo (in Korean)

Truman, Edwin (2011), “Sovereign Wealth Funds: Is Asia Different?” Peterson Institute for International Economics Working Paper 11-12

Yang, Yang-Hyeon and Haerim Lee (2008), "An Analysis of the Attractions of Arbitrage Transactions and of Domestic Bond Investment by Foreigners and Korean Branches of Foreign Banks," Bank of Korea Monthly Bulletin, August (in Korean)

Yi-Chong, Xu and Gawdat Bahgat (2010), The Political Economy of Sovereign Wealth Funds, Palgrave MacMillan 


\section{APPENDIX 1}

Korea's FX Liquidity Crisis of 2008-2009

The following chart effectively shows what happened before (2005-2006) and during (2008-2009) the crisis. The chart is originally from Kim (2010a).

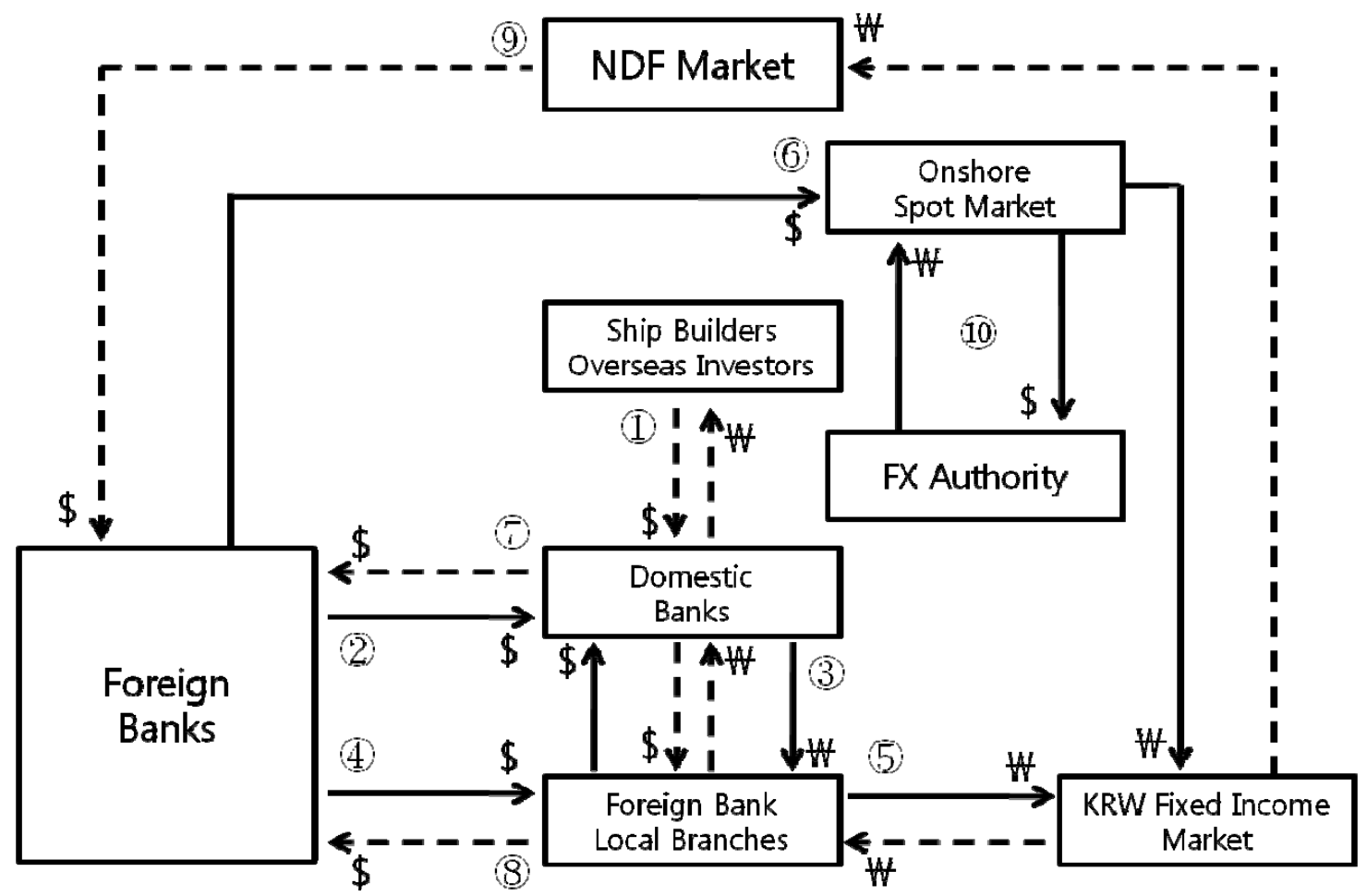

Before the dollar liquidity crisis:

(1) Korean shipping companies and overseas portfolio investors sell dollar forwards to Korean banks.

(2) Korean banks borrow dollar loans, mostly in short-term, from foreign banks

(3) Korean banks enter swap agreements (spot buy \& forward sell) with foreign bank Seoul branches.

(4) Local branches of foreign banks borrow dollar loans, mostly in short-term, from parent banks.

(5) Local branches of foreign banks invest in KRW-denominated fixed income securities.

(6) Foreign banks directly engage in dollar carry trading.

After the dollar liquidity crisis:

(7) Foreign banks stop rolling-over short loans to Korean banks.

(8) Foreign banks stop rolling-over short loans to their Korean braches.

(9) Korean banks that sold dollars forward experience a loss

(10) Market intervention by FX authority (MOSF and BOK) 


\section{APPENDIX 2 \\ FX Risk Hedging by Korean Banks ${ }^{83}$}

Suppose a Korean bank entered a forward contract with a shipbuilding company, the former taking a long position in USD and the latter taking a short position. This bank's balance sheet and foreign exchange position will be as follows.

Balance Sheet

\begin{tabular}{l}
\hline On B/S \\
Off $\mathrm{B} / \mathrm{S}$ \\
Buy forward \\
\hline
\end{tabular}

FX Position

\begin{tabular}{cc}
\hline Spot Position & 0 \\
\hline Forward Position & +100 USD \\
Buy forward & +100 USD \\
\hline Overall Position & +100 USD \\
\hline
\end{tabular}

This bank, with its long USD position, will experience a translation loss if the value of the USD falls against the KRW. To hedge against this, it needs to square the position, and this can be achieved in the following four ways. During the pre-crisis period, Korean banks mainly took the last three measures.

1. USD Forward Sell

If this bank enters a separate forward contract (100 USD) and takes a short position, it can square out the original long position. Since this does not involve any transactions in the spot market, there will be no pressure on the KRW-USD spot rate.

Balance Sheet

\begin{tabular}{rr}
\hline On B/S & \\
\hline Off B/S & +100 USD \\
Buy forward & +100 USD \\
Sell forward & \\
\hline
\end{tabular}

FX Position

\begin{tabular}{cr}
\hline Spot Position & 0 \\
\hline Forward Position & 0 \\
Buy forward & +100 USD \\
Sell forward & -100 USD \\
\hline Overall Position & 0 \\
\hline
\end{tabular}

\section{Currency Return Swap (CRS) Receive + Spot Sell}

An alternative is to enter a CRS receive contract (100 USD) and sell the exact same amount of USD in the spot market. This CRS receive contract allows the bank to enter a short position that will square out the original long position. The contract also increases the bank's USD deposits. To square out this newly created long position, it needs to sell USD in the spot market, which will lower the level of USD deposits to its original level. Since this alternative involves a spot sell, there will be a downward pressure on the KRW-USD spot rate.

${ }^{83}$ This appendix is originally from Kim (2010a). 


\begin{tabular}{cc}
\hline On B/S & +100 USD \\
USD deposits & -100 USD \\
USD deposits & +100 USD \\
\hline Off B/S & +100 USD \\
Buy forward & \\
Sell forward & \\
\hline
\end{tabular}

\begin{tabular}{cr}
\hline Spot Position & 0 \\
USD deposits & +100 USD \\
USD deposits & -100 USD \\
\hline Forward Position & 0 \\
Buy forward & +100 USD \\
Sell forward & -100 USD \\
\hline Overall Position & 0 \\
\hline
\end{tabular}

3. Foreign Exchange Swap (FX Swap) Buy \& Sell + Spot Sell

Another alternative is to enter an FX swap contract (100 USD) that involves a spot buy and a forward sell. Forward sell allows the bank to enter a short position that will square out the original long position. Since the contract involves a spot buy, it increases the bank's USD deposits. To square out this newly created long position, it needs to sell USD in the spot market, which will lower the level of USD deposits to its original level. Since this alternative also involves a spot sell, there will be a downward pressure on the KRW-USD spot rate. The balance sheet and the FX position table will be exactly same as those under CRS receive plus spot sell.

Balance Sheet

\begin{tabular}{cc}
\hline On B/S & +100 USD \\
USD deposits & -100 USD \\
USD deposits & +100 USD \\
\hline Off B/S & +100 USD \\
Buy forward & \\
Sell forward & \\
\hline
\end{tabular}

FX Position

\begin{tabular}{cr}
\hline Spot Position & 0 \\
USD deposits & +100 USD \\
USD deposits & -100 USD \\
\hline Forward Position & 0 \\
Buy forward & +100 USD \\
Sell forward & -100 USD \\
\hline Overall Position & 0 \\
\hline
\end{tabular}

\section{Dollar Borrowing + Spot Sell}

Lastly, the bank can borrow USD (100 USD) and sell the exact same amount in the spot market. Since dollar borrowing will increase the bank's USD deposits, borrowing itself does not square out the original long position. It needs to sell USD in the spot market, and thereby create a short position. This will lower the USD deposits to its original level. Since this measure also involves a spot sell, there will be a downward pressure on the KRW-USD spot rate.

Balance Sheet

\begin{tabular}{lr}
\hline On B/S & \\
USD borrowings & +100 USD \\
USD deposits & +100 USD \\
USD deposits & -100 USD \\
\hline Off B/S & +100 USD \\
Buy forward & \\
\hline
\end{tabular}

FX Position

\begin{tabular}{cr}
\hline Spot Position & -100 USD \\
USD borrowings & -100 USD \\
USD deposits & +100 USD \\
USD deposits & -100 USD \\
\hline Forward Position & +100 USD \\
Buy forward & +100 USD \\
\hline Overall Position & 0 \\
\hline
\end{tabular}

-38 - 
Figure 1: Four Guiding Principles When Designing the Governance Structure of KIC
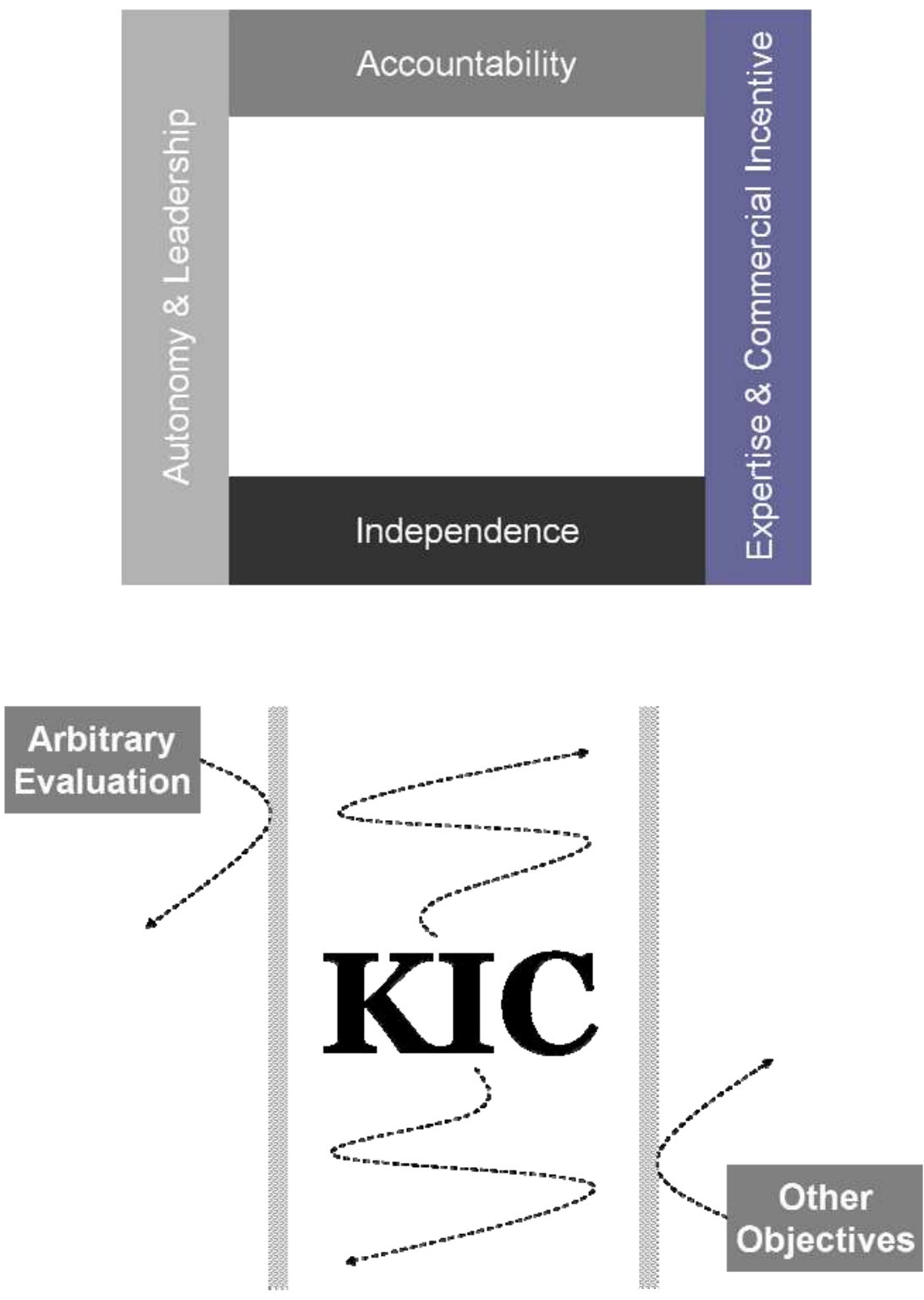
Figure 2: Korea's Financial Account Surplus (million USD, July 1997 - March 2000)

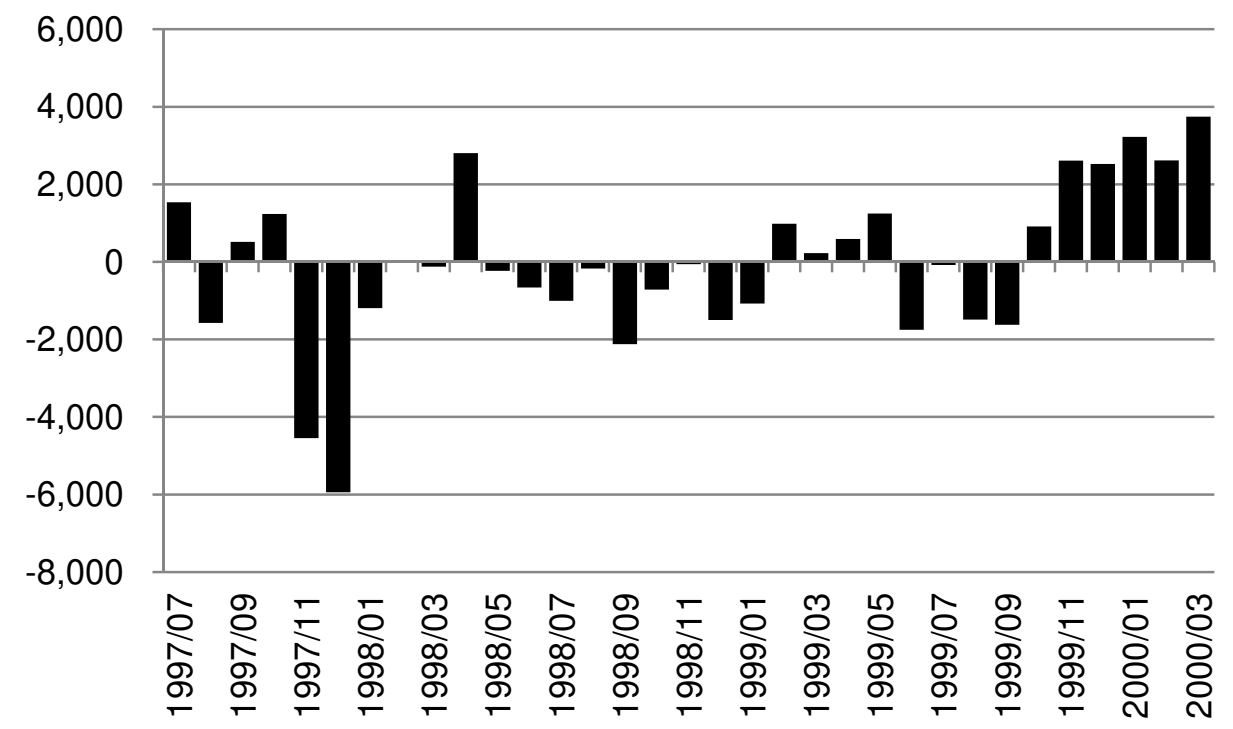

Source: Bank of Korea (BOK)

Figure 3: Korea's FX Reserve (billion USD, January 1997 - March 2000)

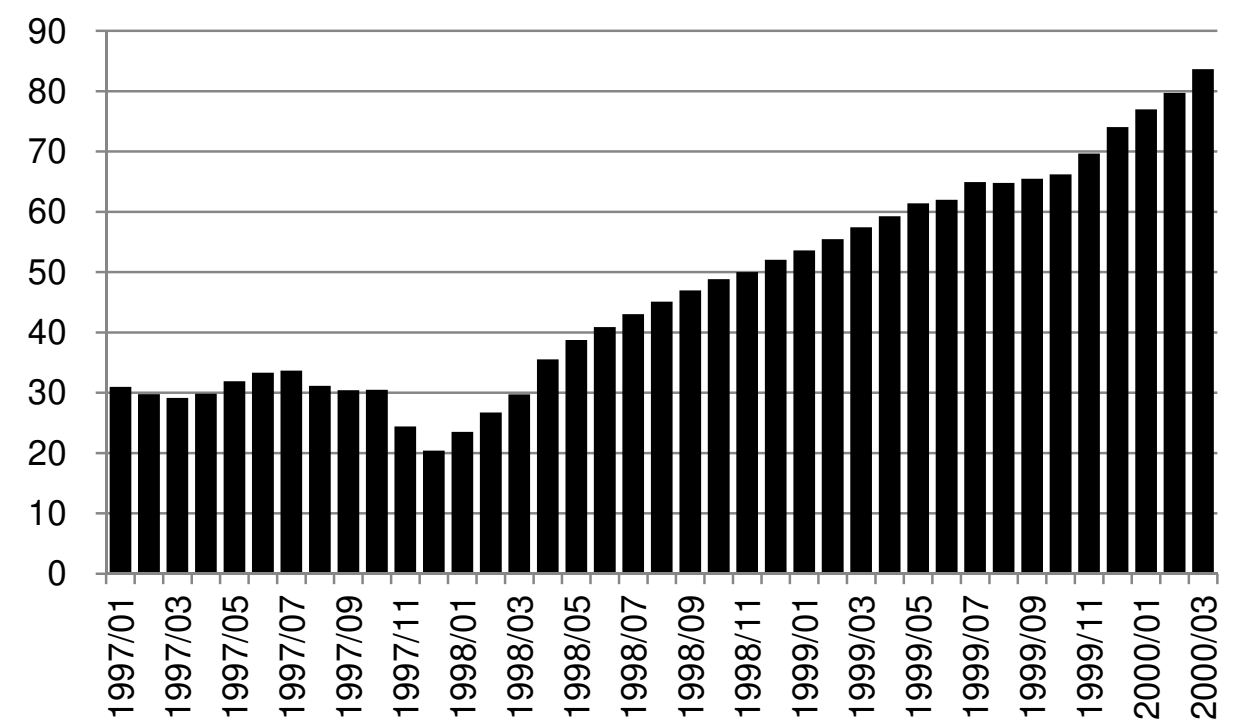

Source: Bank of Korea (BOK) 
Figure 4: US Treasury (2yr) and Korean MSB (2yr) Yield (Mar. 1999 - Dec. 2003)

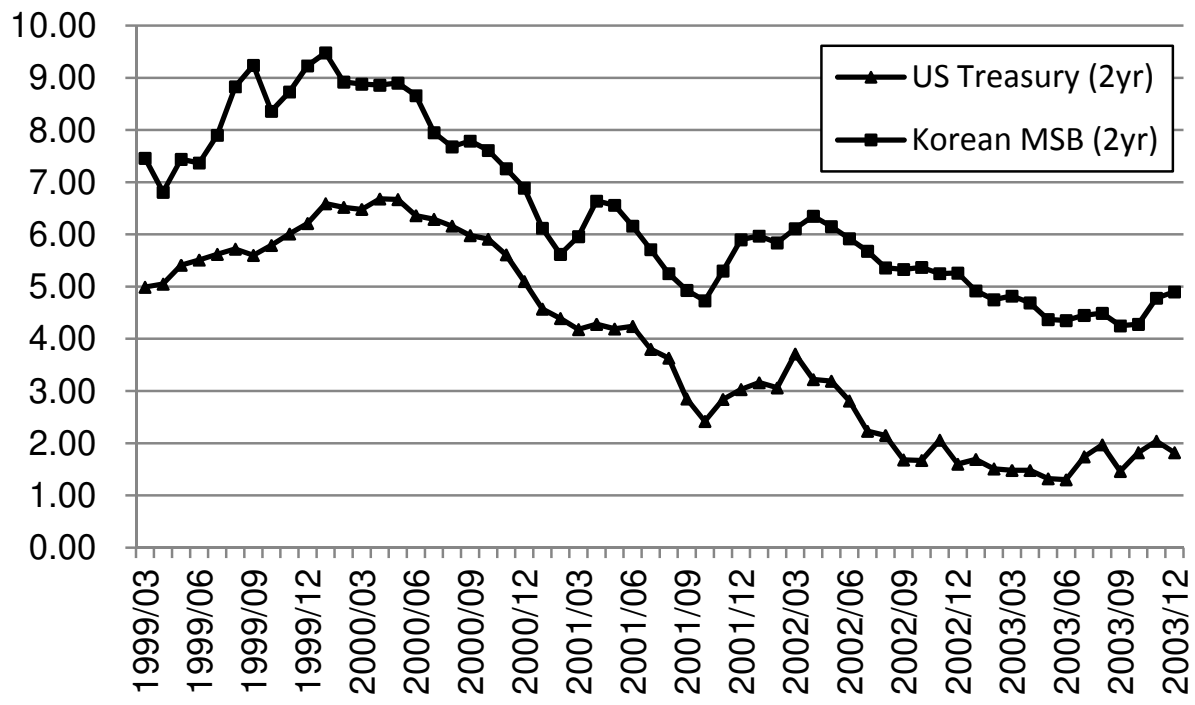

Source: Bank of Korea (BOK)

Figure 5: Korea's FX Reserve and KRW-USD Exchange Rate (2008-2009)

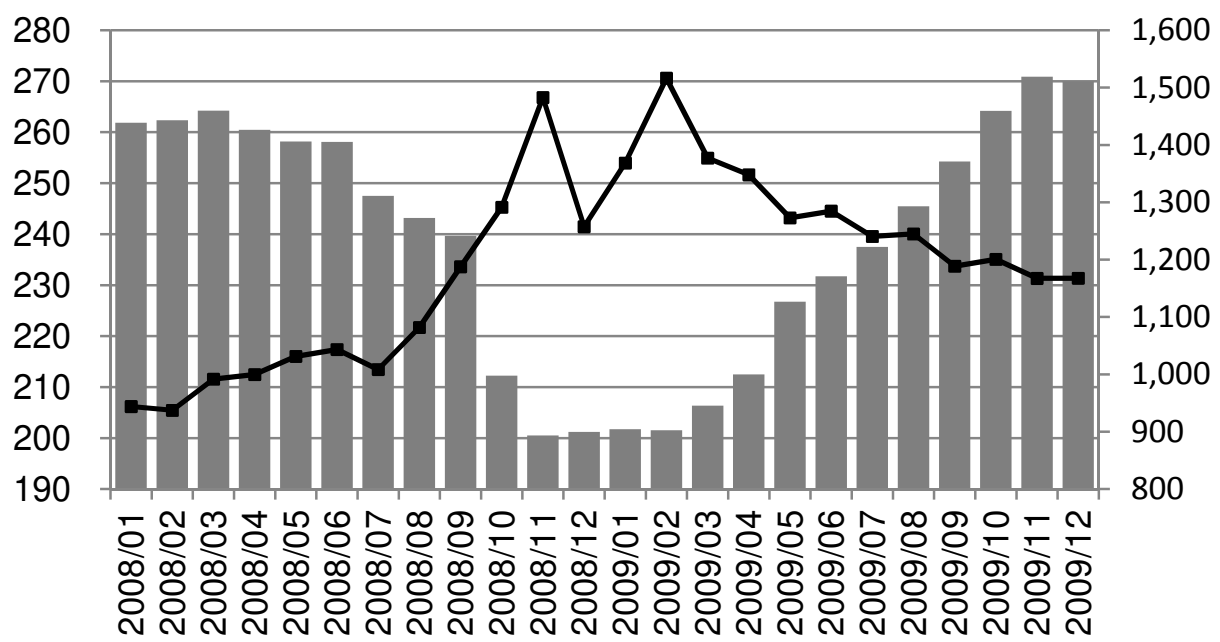

FX Reserve (billion USD) $\rightarrow$ KRW-USD Exchange Rate

Source: Bank of Korea (BOK) 

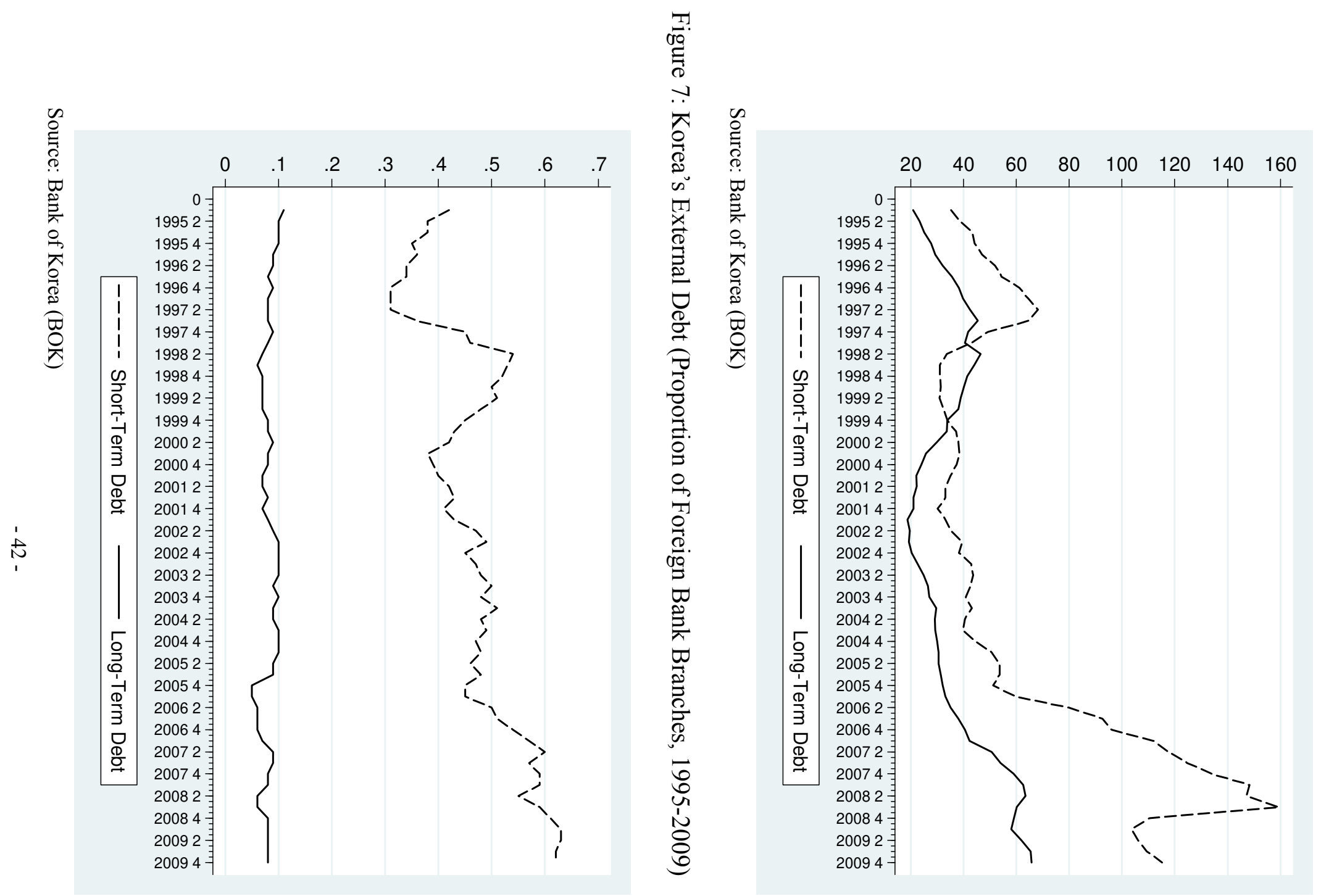

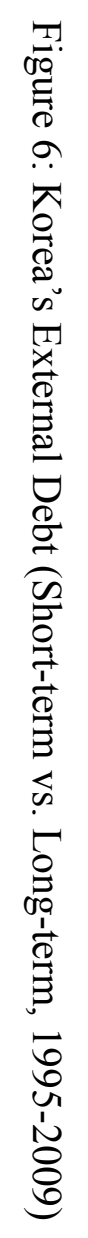



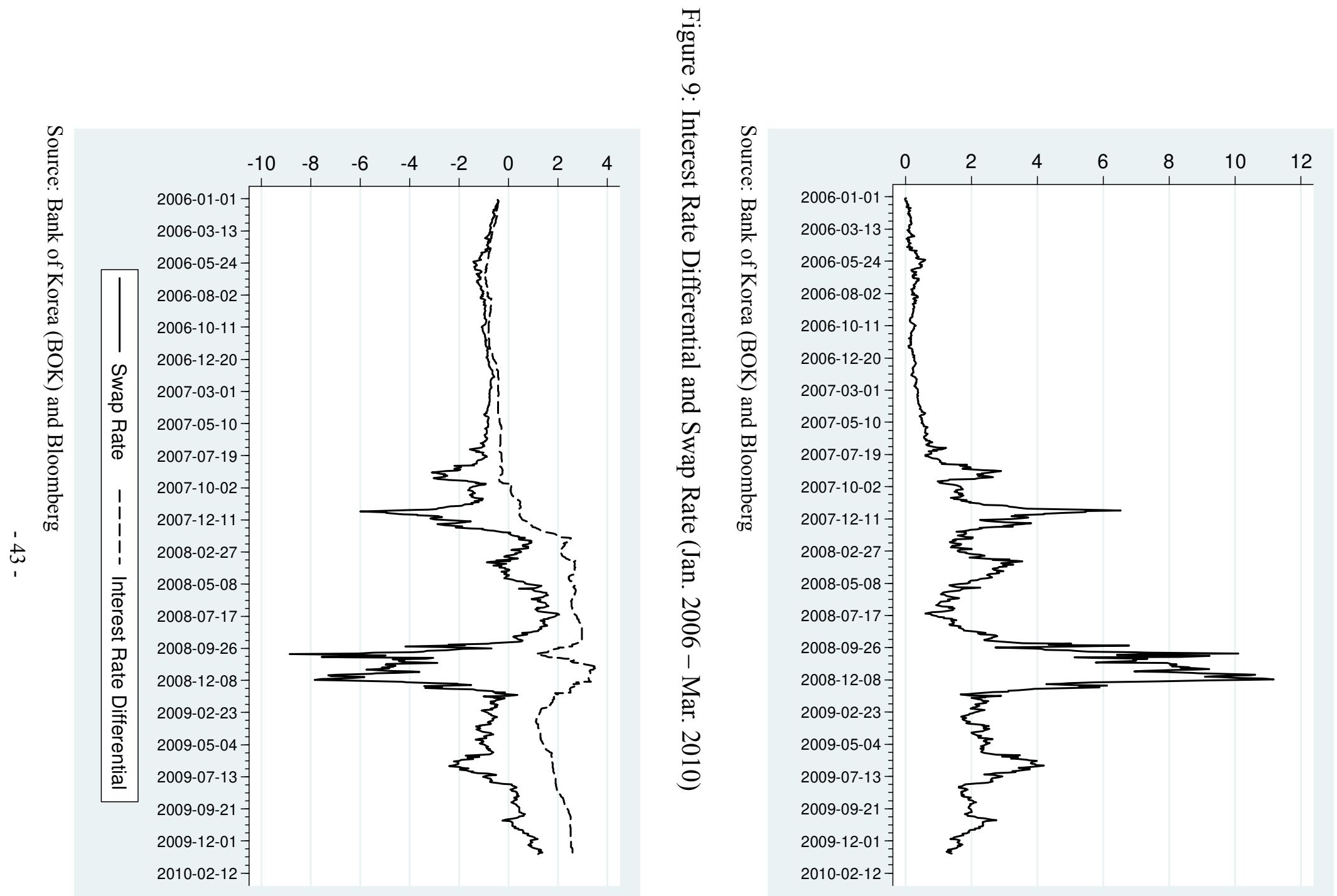

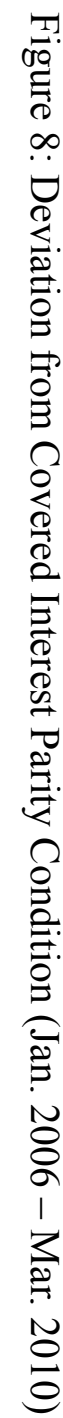


Table 1: Korea's FX Forward Transaction Volume (2005-2008)

(unit: 100 million USD)

\begin{tabular}{lrrrr}
\hline & 2005 & 2006 & 2007 & 2008 (Jan.-Jun.) \\
\hline Forward Sell (A) & 731.6 & $1,127.7$ & $1,531.7$ & 964.6 \\
Ship Building Firms & 223.4 & 430.5 & 622.8 & 403.3 \\
Others & 493.2 & 566.2 & 636.9 & 524.3 \\
Overseas Portfolio Investors & 15.0 & 131.0 & 272.0 & 37.0 \\
\hline Forward Buy (B) & 424.7 & 503.8 & 542.0 & 344.1 \\
Oil Refinery Firms & 60.7 & 10.1 & 25.1 & 33.1 \\
Others & 364.0 & 493.7 & 516.9 & 311.0 \\
\hline A - B & 306.9 & 623.9 & 989.7 & 620.5 \\
\hline
\end{tabular}

Source: Yang and Lee (2008)

Table 2: KIC's Asset Allocation

(unit: million USD)

\begin{tabular}{llrr}
\hline & Asset Class & AUM (US\$mn) & Weight (\%) \\
\hline Traditional Assets & Public Equities & 15,711 & 41.8 \\
& Public Bonds & 17,229 & 45.9 \\
& Inflation-linked Bonds & 527 & 1.4 \\
& Cash, other & 622 & 1.7 \\
\hline \multirow{2}{*}{ Alternative Assets } & Commodities & 485 & 1.3 \\
& Private Equity & 670 & 1.8 \\
& Hedge Funds & 500 & 1.3 \\
& Real Estate & 430 & 1.1 \\
\hline Special Investments & Finance & 1,379 & 3.7 \\
& Energy (Chesapeake, Laricina, Osum) & 37,553 & 100.0 \\
\hline Total & & &
\end{tabular}

Source: KIC Annual Report (2010)

Table 3: KIC's Investment Performance

\begin{tabular}{|c|c|c|c|c|c|c|c|c|c|c|}
\hline \multirow[t]{2}{*}{ Asset Class } & \multicolumn{5}{|c|}{ Returns } & \multicolumn{5}{|c|}{ Excess Return } \\
\hline & 2007 & 2008 & 2009 & 2010 & $\begin{array}{r}\text { Since } \\
\text { Inception }\end{array}$ & 2007 & 2008 & 2009 & 2010 & $\begin{array}{r}\text { Since } \\
\text { Inception }\end{array}$ \\
\hline Fixed Income & 9.91 & 3.81 & 8.56 & - & - & 0.09 & -1.36 & 1.71 & - & - \\
\hline Equities & 5.19 & -41.43 & 31.96 & - & - & -1.19 & -0.11 & -0.23 & - & - \\
\hline Traditional Assets & 7.40 & -13.71 & 18.67 & 8.46 & 20.08 & -0.25 & -0.66 & 1.42 & 0.05 & -0.07 \\
\hline
\end{tabular}

Source: KIC Annual Reports (2007-2010) 